\title{
The benefits of spatial resolution increase in global simulations of the hydrological cycle evaluated for the Rhine and Mississippi basins
}

\author{
Imme Benedict $^{1}$, Chiel C. van Heerwaarden ${ }^{1}$, Albrecht H. Weerts ${ }^{2,3}$, and Wilco Hazeleger ${ }^{1,4}$ \\ ${ }^{1}$ Meteorology and Air Quality Group, Wageningen University, Droevendaalsesteeg 4, 6708 BP Wageningen, the Netherlands \\ ${ }^{2}$ Hydrology and Quantitative Water Management Group, Wageningen University, \\ Droevendaalsesteeg 4, 6708 BP Wageningen, the Netherlands \\ ${ }^{3}$ Deltares, P.O. Box 177, $2600 \mathrm{MH}$ Delft, the Netherlands \\ ${ }^{4}$ Netherlands eScience Center (NLeSC), Science Park 140, 1098 XG Amsterdam, the Netherlands
}

Correspondence: Imme Benedict (imme.benedict@wur.nl)

Received: 13 August 2018 - Discussion started: 21 August 2018

Revised: 28 January 2019 - Accepted: 20 February 2019 - Published: 2 April 2019

\begin{abstract}
To study the global hydrological cycle and its response to a changing climate, we rely on global climate models (GCMs) and global hydrological models (GHMs). The spatial resolution of these models is restricted by computational resources and therefore limits the processes and level of detail that can be resolved. Increase in computer power therefore permits increase in resolution, but it is an open question where this resolution is invested best: in the GCM or GHM. In this study, we evaluated the benefits of increased resolution, without modifying the representation of physical processes in the models. By doing so, we can evaluate the benefits of resolution alone. We assess and compare the benefits of an increased resolution for a GCM and a GHM for two basins with long observational records: the Rhine and Mississippi basins. Increasing the resolution of a GCM (1.125 to $0.25^{\circ}$ ) results in an improved precipitation budget over the Rhine basin, attributed to a more realistic large-scale circulation. These improvements with increased resolution are not found for the Mississippi basin, possibly because precipitation is strongly dependent on the representation of still unresolved convective processes. Increasing the resolution of the GCM improved the simulations of the monthly-averaged discharge for the Rhine, but did not improve the representation of extreme streamflow events. For the Mississippi basin, no substantial differences in precipitation and discharge were found with the higher-resolution GCM and GHM. Increasing the resolution of parameters describing vegetation and orography in the high-resolution GHM (from 0.5 to $0.05^{\circ}$ ) shows no significant differences in discharge for both basins. A straightforward resolution increase in the GHM is thus
\end{abstract}

most likely not the best method to improve discharge predictions, which emphasizes the need for better representation of processes and improved parameterizations that go hand in hand with resolution increase in a GHM.

\section{Introduction}

Hydrometeorological extremes present a combination of atmospheric and hydrological processes. On a global scale, these processes are simulated by forcing global hydrological models (GHMs) with global climate models (GCMs). With these, we can forecast and generate future projections of the hydrological cycle and its extremes. However, the spatial resolution of climate and hydrological models limits the details that can be resolved in a numerical simulation. With higher spatial resolution, and therefore better resolved flows and better represented landscapes, we expect more accurate results when modelling the impact of climate on hydrological processes. However, computer capabilities are limited. Currently, the common horizontal resolution of GCMs in the Coupled Model Intercomparison Project Phase 5 (CMIP5) is around $150 \mathrm{~km}$ (K. E. Taylor et al., 2012). For GHMs, in the Inter-Sectoral Impact Model Intercomparison Project (ISIMIP), this resolution is around $50 \mathrm{~km}$ (Haddeland et al., 2011; Schellekens et al., 2017; Beck et al., 2016).

To improve the detail level at catchment scale, it is a dilemma whether to use high-resolution global models or regional downscaling. High-resolution global climate models lead to better resolved large-scale processes (Scaife et al., 
2011; Jung et al., 2012; Demory et al., 2014; Hodges et al., 2011), cyclones (Strachan et al., 2013; Manganello et al., 2012), and more pronounced small-scale extremes. For hydrological modelling, an increase in resolution leads to improved spatial representation of topography, soil, and vegetation (Wood et al., 2011), and therefore can result in more realistic surface runoff and evaporation. However, increasing the resolution of a GHM also results in increasing unknown, and often not easily quantifiable, model parameters. This brings in large uncertainties when modelling hydrology across multiple spatial scales. There are multiple ongoing initiatives that assess the benefits of global models with very high spatial resolution for both the atmosphere (High Resolution Model Intercomparison Project; Meehl et al., 2014; Haarsma et al., 2016) and in hydrology (Wood et al., 2011; Bierkens et al., 2015).

In parallel to the research on global modelling, hydrological studies often use downscaled weather and climate variables to study regional climate variations and their hydrological impact (Jacob et al., 2014), as the spatial resolution of a basin can be substantially increased compared to a global model. Although dynamical downscaling has many benefits, it is not able to reduce biases that are related to errors in largescale circulation patterns (Maraun et al., 2017; Van Haren et al., 2015), which are related to the low-resolution GCMs used as boundary conditions for the downscaled products (Hazeleger et al., 2015; Fowler et al., 2007; Wood et al., 2004).

Here, we study the effect of resolution in global models on stimulating the hydrological cycle at the basin scale. The hypothesis of this study is that with higher-resolution climate and hydrological models the hydrological cycle will be better simulated. We focus on two contrasting large river basins, the Rhine and Mississippi basins. To study the effect of an increased spatial resolution, we compare low- and highresolution simulations of a global climate model, as well as of a global hydrological model over these two basins. By comparing all cross-combinations of resolutions (Fig. 1), we aim to answer our main research question: what are the benefits of an increased resolution global climate and global hydrological model in simulating the hydrological cycle over the Rhine and Mississippi basins?

We analyse three main components of the hydrological cycle: precipitation, evaporation, and discharge. We have chosen the Rhine and Mississippi basins as long measurement records are available for validation, and because their climatic drivers are different, which can contribute to our understanding of the processes resolved with increased spatial resolution. The precipitation budget of the moderately sized Rhine basin is determined by the mid-latitude storm track, which is shown to be better represented with higherresolution models (e.g. Davini et al., 2017a; Van Haren et al., 2015; Zappa et al., 2013). On the other hand, the precipitation budget of the Mississippi is influenced by moisture input from multiple drivers; moisture is advected from the Pacific,
Table 1. Basin characteristics of the two study basins, including basin area, used gauge station, and its average discharge there.

\begin{tabular}{lrlr}
\hline Basin & $\begin{array}{r}\text { Basin } \\
\text { area } \\
\left(\mathrm{km}^{2}\right)\end{array}$ & $\begin{array}{l}\text { Gauge } \\
\text { station }\end{array}$ & $\begin{array}{r}\text { Average } \\
\text { discharge } \\
\left(\mathrm{m}^{3} \mathrm{~s}^{-1}\right)\end{array}$ \\
\hline Rhine & 165000 & Lobith & $\begin{array}{r}2200 \\
\text { Mississippi }\end{array}$ \\
2981100 & Vicksburg & 16500 \\
\hline
\end{tabular}

from the Caribbean, and from the Gulf of Mexico, and extreme precipitation occurs within tropical cyclones (Fig. 2). In addition, convective precipitation plays an important role over the Mississippi basin (Iorio et al., 2004). Although the Rhine and Mississippi are two contrasting basins, they do not represent the full diversity of catchments on a global scale. It would be computationally too expensive to study more regions.

The paper is structured as follows: more details about the basins are given in Sect. 2. In Sect. 3 the models, data, and methods are described. We first present the results for the Rhine basin and thereafter for the Mississippi basin. The methodology of this study, as well as the broader implications, are discussed in Sect. 5, and we end with a conclusion and summary (Sect. 6).

\section{Basin description: Rhine and Mississippi}

The River Rhine originates in the Swiss Alps and flows through Switzerland, Germany, and the Netherlands, where it discharges into the North Sea. In this study, we analyse discharge at Lobith, which is the location where the Rhine enters the Netherlands. Therefore the basin is defined upstream of Lobith (measuring about $165000 \mathrm{~km}^{2}$; see Table 1). The average discharge at Lobith is $2200 \mathrm{~m}^{3} \mathrm{~s}^{-1}$ and the highest discharges occur in late winter and spring. During this period large-scale rainfall events, associated with storms, occur over saturated soils, which can lead to extreme flood events. Snowmelt, in combination with frozen soils, can occasionally lead to extreme flood events as well (Hegnauer et al., 2014).

The Mississippi basin is more than 16 times larger than the Rhine basin. It measures $2981000 \mathrm{~km}^{2}$ (Table 1), which makes it the fourth-largest river basin in the world. The Mississippi River originates at Lake Itasca, Minnesota, from where it flows south towards the Gulf of Mexico. The two largest tributaries of the Mississippi are the Missouri and Ohio rivers. Here, we study the discharge of the Mississippi basin at Vicksburg, where the average discharge is $16500 \mathrm{~m}^{3} \mathrm{~s}^{-1}$ (Table 1). Most flood events occur in winter and spring due to heavy (excess) precipitation, snowmelt, and rain-on-snow events (Berghuijs et al., 2016; Van der Wiel et al., 2018). 


\begin{tabular}{|cc|}
\hline Global climate model (GCM) & Global hydrological model (GHM) \\
\hline Coarse resolution $(120 \times 120 \mathrm{~km})$ & Coarse resolution $(50 \times 50 \mathrm{~km})$ \\
\hline High resolution $(25 \times 25 \mathrm{~km})$ & High resolution $(5 \times 5 \mathrm{~km})$ \\
\hline
\end{tabular}

Figure 1. Two spatial resolution simulations of the GCM are used to force the GHM with two different spatial resolutions. Note that this set-up was tested for two large river basins, the Rhine and Mississippi basins.

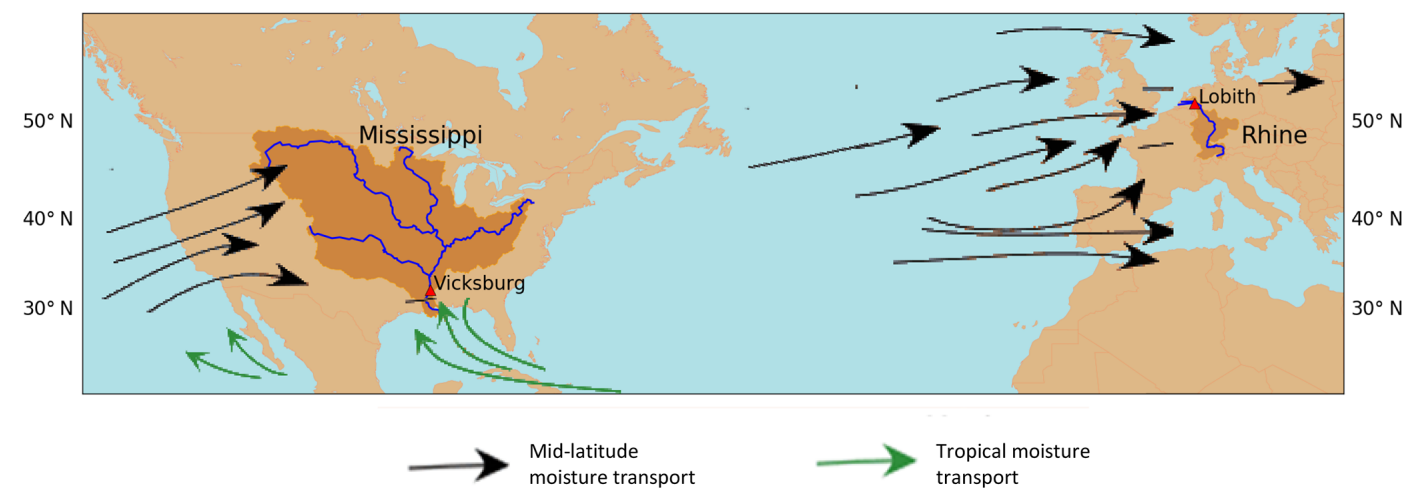

Figure 2. Map indicating the Rhine and Mississippi basins, the rivers, the used gauge stations (Lobith and Vicksburg), and the climatological location of mid-latitude moisture transport (black arrows) and tropical moisture transport (green arrows). Figure adapted from http://www. physicalgeography.net/fundamentals/7s.html.

\section{Data and methodology}

\subsection{Global climate model EC-Earth}

We use high-resolution experiments (Haarsma et al., 2013) from the EC-Earth V2.3 state-of-the-art atmospheric global climate model (Hazeleger et al., 2010; Hazeleger et al., 2012). EC-Earth is based on European Centre for MediumRange Weather Forecasts numerical weather prediction model Integrated Forecasting System (IFS) cy31r1. An improved hydrology scheme (H-TESSEL; Balsamo et al., 2009; Van den Hurk et al., 2000) is inserted into EC-Earth, compared to IFS. Actual evaporation is generated from this scheme by solving the energy balance for specific land tiles. EC-Earth is forced with prescribed sea surface temperatures (SSTs), based on observations in current climate (NASA data at $0.25^{\circ}$ resolution; for details we refer the reader to Haarsma et al., 2013). Observed greenhouse gases and aerosol concentrations are also used as boundary conditions.

The high-resolution experiments have a horizontal spectral resolution of T799, which corresponds to $25 \mathrm{~km}$, and 91 vertical levels (further referred to as high and T799). For comparison in resolution, the same model simulations are performed with a spectral horizontal resolution of T159, corresponding to $120 \mathrm{~km}$ and 62 vertical levels (further referred to as low and T159). The parameterization packages of the high- and low-resolution simulations are the same (Van Haren et al., 2015). The land-surface characteristics are described in the IFS model documentation (2007, IFS Doc- umentation cy31r1, ECMWF) and are interpolated to the requested resolutions (T799 and T159). For both resolutions, six members of 5 years (2002-2006) are created, resulting in 30 years of data representing the present climate. It should be noted that the fixed boundary conditions (SST and greenhouse forcing) decrease the independency of the members and that this research could also be performed with fewer longer simulations. More information on the experiment and the spin-up can be found in Haarsma et al. (2013).

\subsection{Global hydrological model W3RA}

W3RA is the global hydrological model that we use in this study. It is based on the landscape hydrology component model of the AWRA system (AWRA-L; Van Dijk et al., 2013; Van Dijk and Warren, 2010; Van Dijk, 2010a; van Dijk and Renzullo, 2011). AWRA-L can be considered a hybrid between a simplified grid-based land-surface model and a non-spatial, or so-called lumped, catchment model applied to individual grid cells. The model consists of two hydrological response units (HRUs), deep-rooted tall vegetation (forest), and shallow-rooted short vegetation (herbaceous), each of them occupying a fraction of a grid cell. Vertical processes are described for each HRU individually. There is no lateral redistribution of water between grid cells. This lack of lateral flow does not degrade the water balance (Van Dijk, 2010a). The model consists of three soil layers and runs with a daily time step. Actual evaporation is calculated with the energy balance. For full technical details about the model algorithm and parameters, we refer to the technical documen- 
tation (Van Dijk, 2010a). The main evaluation of the model on a global scale is documented in Van Dijk et al. (2013). The model does not contain reservoirs.

Although W3RA is a global model, in this study we only perform the simulations for the Rhine and Mississippi basins. We run the model at the original horizontal resolution of $0.5^{\circ}(\sim 50 \mathrm{~km})$ and at a higher horizontal resolution of $0.05^{\circ}$ $(\sim 5 \mathrm{~km})$. The parameters in $\mathrm{W} 3 \mathrm{RA}$ at $0.5^{\circ}$ resolution are determined with a regionalization approach (van Dijk, 2010b). The list of parameters can be found in the documentation (Van Dijk, 2010a). Most of these parameters are not physically based and are difficult to determine at multiple spatial scales. To allow a fair comparison between the two model resolutions, we remapped these parameters from the 0.5 to the $0.05^{\circ}$ resolution using area-weighted interpolation. Our approach is verified by Melsen et al. (2016), who conclude that parameters can to a large extent be transferred across the spatial resolution (on regional scales from 1 to $100 \mathrm{~km}^{2}$ ). We only make an exception for orography and vegetation, as these parameters are known at high resolution. Therefore, maps of orography and vegetation (division of HRU per grid cell) are used at the $0.05^{\circ}$ resolution. The model algorithm is not adapted for the higher resolution.

The resolution of the GHM does not perfectly coincide with the resolution of the GCM (see Fig. 1). Therefore, we remap the climate variables in between using closest distance interpolation. Runoff is translated towards discharge using the wflow routing scheme (Schellekens, 2016), which is based on the kinematic wave approximation. For the $0.5^{\circ}$ resolution GHM, routing is performed at $0.5^{\circ}$. For the $0.05^{\circ}$ resolution GHM, routing is performed at $0.083^{\circ}$ as the maps of the river network are available at this resolution from the PCR-GLOBWB model (Sutanudjaja et al., 2018). We use closest distance interpolation to remap the runoff data from $0.05^{\circ}$ towards $0.083^{\circ}$. For each member, we perform a spinup cycle of 5 years to generate the initial conditions for the simulations of 5 years, from which we use the last 4 years for the analysis. With a soil depth of $5 \mathrm{~m}$, we expect that the land surface will be in equilibrium after 6 years. When using the last 4 years of the simulation, hardly any effect of the initial conditions is found (results not shown). To summarize, we have 24 years of discharge simulations per combination of resolutions.

\subsection{Observational datasets for model verification}

We use the E-OBS dataset version 12.0 (Haylock et al., 2008) at $0.25^{\circ}$ from 1985 until 2015 (30 years) for precipitation comparison over the Rhine basin. For extra verification, we use the genRE precipitation dataset (van Osnabrugge et al., 2017), which is hourly data over the Rhine basin available from 1996 to 2015. For the Mississippi basin, the Climate Prediction Center (CPC) $0.25^{\circ}$ Daily US Unified GaugeBased precipitation dataset version 1.0 (Higgins et al., 2000) is used from 1985 to 2015 (30 years).
For the verification of actual evaporation, we use the GLEAM (Global Land Evaporation: the Amsterdam Methodology) dataset version 3.0a (Martens et al., 2017) from 1985 until 2015 (30 years). This product is primarily driven by potential evaporation estimates using PriestleyTaylor (Priestley and Taylor, 1972) and by passive microwave remote sensing data.

Daily discharge data for the Rhine at Lobith and the Mississippi at Vicksburg are obtained from the Global Runoff Data Center (GRDC, 2007) from 1985 until 2015 (30 years).

In addition to the observational datasets, we verify our model results with reanalysis data from the ECMWF. A global atmospheric reanalysis, ERA-Interim (Dee et al., 2011; further referred to as ERAI), is used from 1985 up to 2014 (30 years). ERA-Interim has a spatial resolution of around $80 \mathrm{~km}$ and 60 vertical levels (T255L60) and is based on IFS release Cy31r2 (comparable to Cy31r1 used in the EC-Earth simulations), which includes the land-surface TESSEL scheme (Viterbo and Beljaars, 1995). In addition, the ERA-Interim/Land reanalysis (Balsamo et al., 2013) is shortly addressed, where precipitation from ERA-Interim is corrected with satellite data, and an improved land-surface scheme, H-TESSEL, is used (Balsamo et al., 2009). ERAInterim/Land is only available until 2010 and therefore we analyse the time series from 1985 until 2010. Lastly, the ERA20C dataset (Poli et al., 2016) is used for extra verification of the precipitation budget over the Mississippi (19852010). ERA20C is based on IFS cy38r1 and performs the assimilation on fewer variables than ERA-Interim.

\subsection{Experimental set-up}

We use the low- and high-resolution GCM EC-Earth to force the low- and high-resolution GHM W3RA (Fig. 1). To test the GHM without the uncertainty of a free-running GCM, we also force the GHM with ERAI data. The forcing of the GHM with the GCM is illustrated in Fig. 3. We use the following variables from the GCM: total precipitation (TP), mean sea level pressure (MSL), temperature and dewpoint temperature at $2 \mathrm{~m}\left(T\right.$ and $\left.T_{\mathrm{d}}\right)$, wind at $10 \mathrm{~m}\left(U_{10}\right.$ and $\left.V_{10}\right)$, and surface solar and thermal radiation (SSR and STR). In the preprocess phase, potential evaporation $\left(E_{\text {pot }}\right)$ is calculated using Penman-Monteith (Monteith, 1965). Then we use potential evaporation, precipitation, temperature, mean sea level pressure, and wind to force the GHM. We do not perform a bias correction on the GCM output.

In this study, we analyse the three main components of the hydrological cycle: precipitation, evaporation, and discharge. First, we analyse precipitation from the GCM, because it is the main and most uncertain forcing variable for hydrological applications (Biemans et al., 2009; Fekete et al., 2004). To get a first impression, we compare simulated and observed spatial distributions of 30-year average daily precipitation sums over the basins. Figure 2 indicates the basin areas. With the monthly averages of basin-averaged precip- 


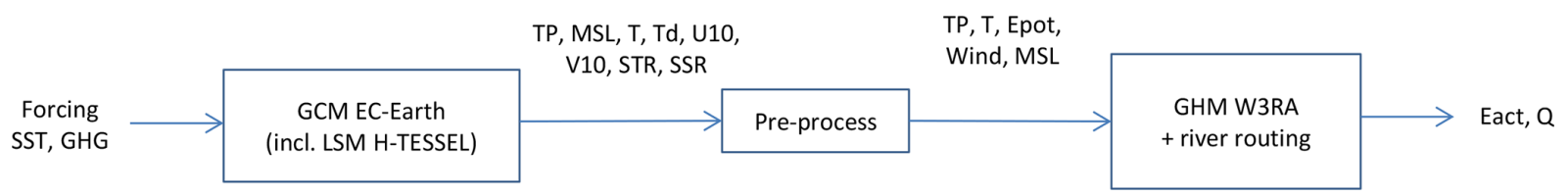

Figure 3. Flowchart illustrating the methodology of this study, including the global climate model, the global hydrological model, and the related variables: total precipitation (TP), mean sea level pressure (MSL), temperature at $2 \mathrm{~m}(T)$, dewpoint temperature at $2 \mathrm{mr}\left(T_{\mathrm{d}}\right)$, wind component $x$ direction at $10 \mathrm{~m}\left(U_{10}\right)$, wind component $y$ direction at $10 \mathrm{~m}\left(V_{10}\right)$, surface solar radiation (SSR), surface thermal radiation (STR), potential evaporation $\left(E_{\text {pot }}\right)$, actual evaporation $\left(E_{\text {act }}\right)$, and discharge $(Q)$.

itation, we compare the seasonal cycle of the observations with the high- and low-resolution GCM and ERAI. The robustness of these results is indicated by $95 \%$ confidence intervals which are obtained after bootstrapping the daily data (Efron and Tibshirani, 1994), assuming all years to be independent. We perform an extra analysis over the Mississippi basin to better understand the precipitation patterns. We focus on the Mississippi, as extensive analysis has already been performed for the Rhine (Van Haren et al., 2015). We analyse the large-scale circulation patterns over the Mississippi basin and we quantify the convective part of precipitation, which plays an important role in this basin.

Furthermore, we statistically assess precipitation extremes by calculating the return time of annual maximum 10-day precipitation sums (van Haren et al., 2013; Shabalova et al., 2003; Kew et al., 2011). We have chosen to analyse 10-day precipitation sums, as multi-day precipitation extremes are mostly connected with extreme discharge (Disse and Engel, 2001; Ulbrich and Fink, 1995). The maxima are rank-ordered and an empirical distribution is applied to determine their return time $T: T=m /(N+1)$, where $m$ is the rank-ordered maxima and $N$ is the number of years in the data (30 years). Gumbel plots show the seasonal 10-day precipitation maxima as a function of the Gumbel variate $x=-\ln (-\ln (T))$, which can be translated into a return time $T$ in years. The plots are made for annual maxima in every season (DJF, MAM, JJA, and SON). These Gumbel plots are only based on 30 data points, which should be taken into account during the interpretation of these plots.

Second, we analyse actual evaporation which couples the physical climate system and hydrology, as it can constitute a feedback between the atmosphere and the land surface. Therefore, actual evaporation $\left(E_{\text {act }}\right)$ is calculated within the global climate and global hydrological model, which allows us to compare the two models. We derive monthly averages of basin-averaged actual evaporation. We only show $E_{\text {act }}$ results from the $0.5^{\circ}$ resolution GHM.

Third, we compare monthly-averaged discharge from the GHM with observations at Lobith (Rhine) and Vicksburg (Mississippi). In addition, we compare three discharge measures as defined in Table $2: \bar{Q}_{\text {mean }}, \bar{Q}_{\text {max }}$, and $\bar{Q}_{\text {min }}$. Finally, we determine the return times of annual maximum discharge per season, by using the same Gumbel distribution as de-
Table 2. Three different discharge measures, $\bar{Q}_{\text {mean }_{h}}, \bar{Q}_{\max _{h}}$, and $\bar{Q}_{\min _{h}}$ are respectively the mean, maximum, and minimum daily discharge of year number $h$, ranging from 1 to 24 . The total number of years $(H)$ is 24 .

\begin{tabular}{lll}
\hline Measure & Explanation & Calculation \\
\hline $\bar{Q}_{\text {mean }}$ & $\begin{array}{l}\text { 24-year average mean } \\
\text { annual discharge }\left(\mathrm{m}^{3} \mathrm{~s}^{-1}\right)\end{array}$ & $\bar{Q}_{\text {mean }}=\frac{1}{H} \sum_{h=1}^{24} Q_{\text {mean }_{h}}$ \\
\hline $\bar{Q}_{\max }$ & $\begin{array}{l}\text { 24-year average annual } \\
\text { maximum discharge }\left(\mathrm{m}^{3} \mathrm{~s}^{-1}\right)\end{array}$ & $\bar{Q}_{\max }=\frac{1}{H} \sum_{h=1}^{24} Q_{\max _{h}}$ \\
\hline $\bar{Q}_{\min }$ & $\begin{array}{l}\text { 24-year average annual } \\
\text { minimum discharge }\left(\mathrm{m}^{3} \mathrm{~s}^{-1}\right)\end{array}$ & $\bar{Q}_{\min }=\frac{1}{H} \sum_{h=1}^{24} Q_{\min _{h}}$ \\
\hline
\end{tabular}

scribed for precipitation. It should be noted that these results are based on 24 years of discharge simulations.

In addition, we aim to better understand the relation between precipitation and discharge. Therefore, we show scatterplots of daily discharge against previous 10-day precipitation sums for both basins, the high- and low-resolution GCMs, and the observations. For the simulations, we only show the discharge results from the $0.5^{\circ} \mathrm{GHM}$, but the results from the $0.05^{\circ} \mathrm{GHM}$ were analysed and will be discussed where appropriate. The correlations are calculated for each season (DJF, MAM, JJA, and SON) and we also include the annual maxima in discharge and 10-day precipitation sums.

All the above-described methods compare observations with model simulations in a statistical way. However, individual high-impact weather events, hydrometeorological extremes, are also relevant. Realistic simulations of individual events are important in forecasts and impact studies, and when assessing the potential effect of anthropogenic climate change. In particular, the emerging field of event attribution requires that events are plausibly simulated with numerical models (Stott et al., 2013; Hazeleger et al., 2015). In addition, single cases are often used as narratives to illustrate the complexity and linkage between components in the hydrometeorological system (Moezzi et al., 2017; Zappa and Shepherd, 2017). Therefore, the performance of this model set-up in describing hydrometeorological extremes is assessed by showing the rainfall-runoff response and synoptic pattern of a selected extreme event for each basin. This serves as an illustration of how the modelling results can be used for study- 


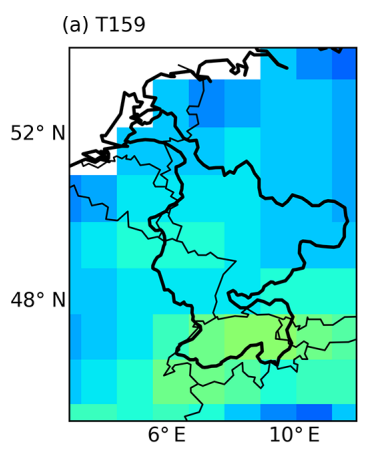

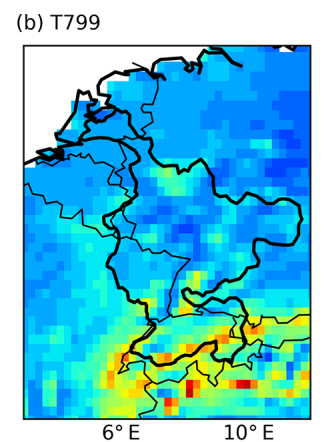

(c) Obs E-OBS
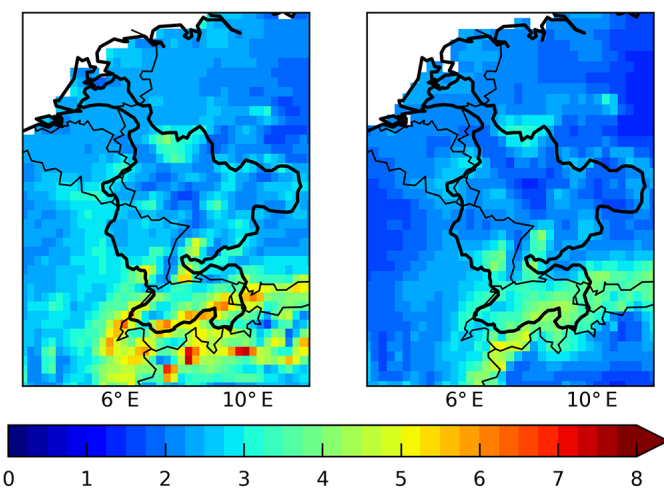

(c) Obs genRE

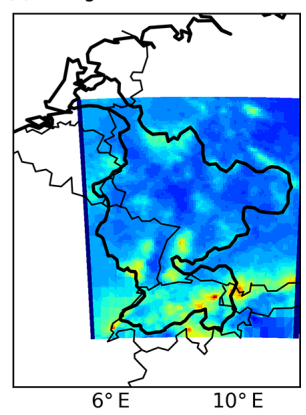

$\mathrm{mm} \mathrm{d}^{-1}$

Figure 4. 30-year average of daily precipitation sums $\left(\mathrm{mm} \mathrm{day}^{-1}\right)$ over the Rhine basin for (a) the low-resolution EC-Earth simulations (T159), (b) the high-resolution EC-Earth simulations (T799), (c) the E-OBS dataset (Obs E-OBS), and (d) the genRE precipitation dataset (Obs genRE).

ing events. We show the results of the high-resolution GCM forcing the low-resolution GHM for the two basins.

\section{Results and discussion}

\subsection{Rhine}

\subsubsection{Precipitation in the Rhine basin}

The EC-Earth simulations and the observations (E-OBS and genRE) show a similar spatial distribution of precipitation over the Rhine basin (Fig. 4), with more precipitation over the Alps (4-5 mm day $\left.{ }^{-1}\right)$ than downstream over western Germany (1-2 mm day $\left.{ }^{-1}\right)$. The high-resolution model shows, as expected, a more detailed distribution. A higherresolution orography reveals spatial structures such as the Alps, Ardennes, and Black Forest. At the locations with large precipitation amounts, slight overestimations are found with the high-resolution model (Fig. 4b). It is unclear whether these overestimations are related to model performance or to underestimation of precipitation in the E-OBS dataset (Turco et al., 2013; van Osnabrugge et al., 2017), as E-OBS is based on a sparse gauge network in mountainous areas (Hofstra et al., 2009) and no correction for undercatch is applied (Prein and Gobiet, 2017). The genRE precipitation dataset shows locally also higher precipitation values compared to EOBS. Besides, it should be noted that not all Alpine, or other topographical, structures are kept within the high-resolution GCM grid of $25 \mathrm{~km}$ by $25 \mathrm{~km}$.

From the basin-averaged precipitation sums in Fig. 5a, we find that both resolutions' GCMs overestimate the observed precipitation amounts. From March until July the high-resolution model outperforms the low-resolution one. Van Haren et al. (2015), who used the same EC-Earth simulations, found similar improvements in high-resolution precipitation for the region that spans the Rhine and Meuse basins.
They attributed this to the better represented storm tracks over Europe in the high-resolution simulations and therefore a more accurate horizontal moisture transport (Fig. 9 in Van Haren et al., 2015). Nevertheless, despite the improvement with resolution, precipitation is still overestimated from January until June in T799 compared to the observations and ERAI (Fig. 5a).

Figure 6 (left panels) shows the influence of resolution on the return time of annual 10-day precipitation maxima per season. During all seasons, and particularly in DJF and MAM, there is a distinct overestimation of precipitation by EC-Earth at lower return times (smaller than 2 years). This is in agreement with the overestimation in the monthly averages of precipitation (Fig. 5a). At higher return times (larger than 2 years), we find an underestimation of precipitation in the GCM data in DJF (Fig. 6a). The extremes in the stormtrack season (SON) are quite well reproduced by the model. By comparing the two model resolutions, we find that in MAM and JJA the high-resolution model outperforms the low-resolution one for all return times, which suggests that with an increased resolution the right large-scale conditions are present to activate convection.

\subsubsection{Actual evaporation in the Rhine basin}

In Fig. 5b we show actual evaporation from GLEAM, ECEarth, ERAI, and the $0.5^{\circ} \mathrm{GHM}$ forced with EC-Earth and ERAI. Actual evaporation $\left(E_{\text {act }}\right)$ is overestimated in all simulations compared to the reference GLEAM, especially in winter $\left(0.5 \mathrm{~mm} \mathrm{day}^{-1}\right)$. This can be related to an overestimation of precipitation in winter, as an increase in precipitation can lead to larger evaporation rates. Actual evaporation from the high resolution shows a smaller bias with observations than the low resolution, which is consistent with our precipitation results. We also find an overestimation of $E_{\text {act }}$ from ERAI compared to GLEAM (Fig. 5b), though precipitation 

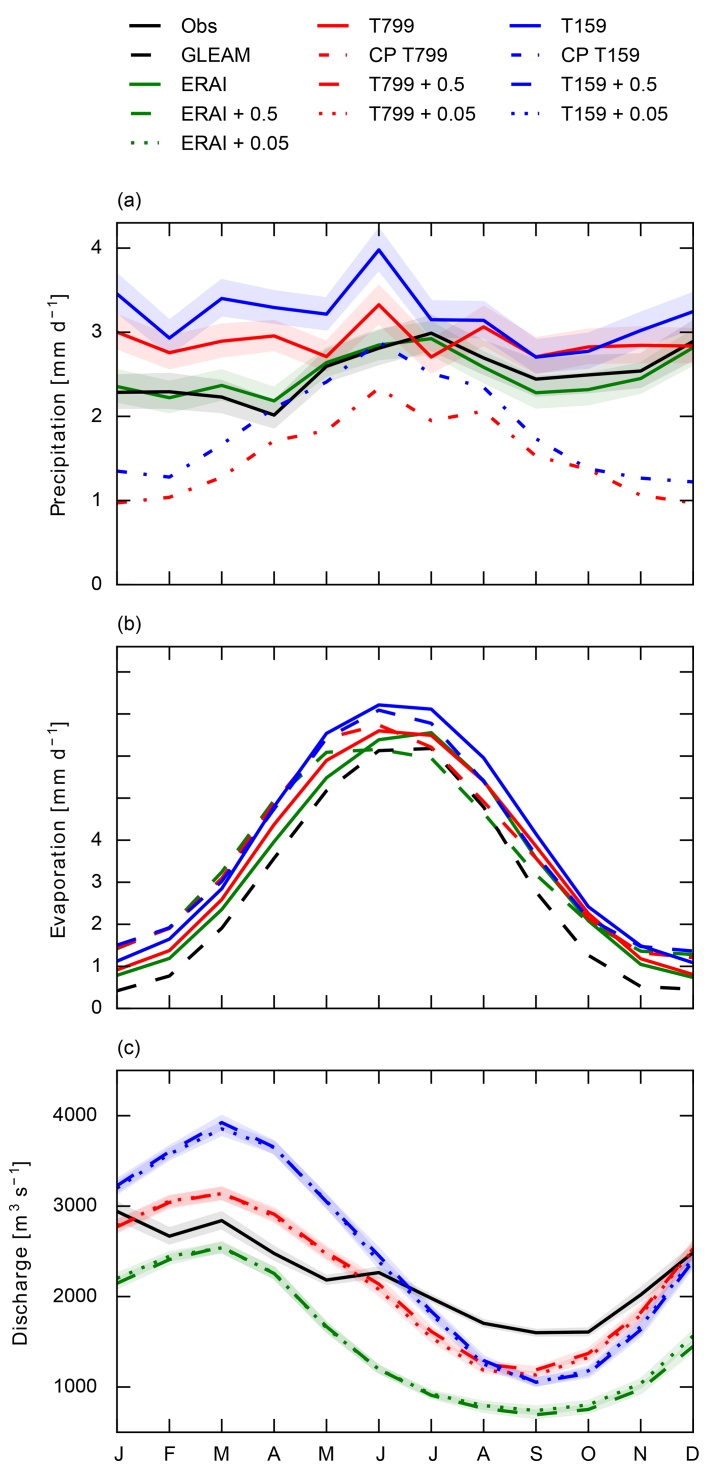

Figure 5. Monthly averages of (a) basin-averaged daily precipitation sums $\left(\mathrm{mm} \mathrm{day}^{-1}\right)$, (b) basin-averaged daily evaporation sums $\left(\mathrm{mm} \mathrm{day}^{-1}\right)$, and (c) daily discharge $\left(\mathrm{m}^{3} \mathrm{~s}^{-1}\right)$ at Lobith for the Rhine basin. Black lines are observations; green is ERAI. The red and blue lines are respectively the high-resolution (T799) and lowresolution (T159) GCMs. The dash-dotted lines indicate convective precipitation, dashed lines output from the $0.5^{\circ} \mathrm{GHM}$, and dotted lines from the $0.05^{\circ} \mathrm{GHM}$. The shaded bands indicate the $95 \%$ confidence intervals.

in ERAI is not overestimated (Fig. 5a). These high evaporation amounts in ERAI can explain the large underestimation of simulated discharge at Lobith, discussed in the next Sect. 4.1.3.

There is a large difference between actual evaporation directly from ERAI and actual evaporation indirectly from the GHM forced with ERAI. This difference is smaller for the EC-Earth simulations. Possibly, this is because of an improved land-surface scheme in EC-Earth (H-TESSEL), while
ERAI is based on the old scheme (TESSEL) that does not contain a seasonal cycle in leaf area index and has a global uniform soil texture (Balsamo et al., 2009).

The yearly-averaged $E_{\text {act }}$ values from the climate and hydrological model are comparable, but there are seasonal differences (Fig. 5b). As both models (GCM and GHM) solve actual evaporation from the energy balance, these differences are related to the vegetation and soil characteristics of the models. Actual evaporation from the GHM is higher in the beginning of the year (January until June) and peaks earlier in the season compared to the GCM (Fig. 5b). Overall, it seems that the $E_{\text {act }}$ from the GCM is in better agreement with the reference GLEAM dataset.

\subsubsection{Discharge in the Rhine}

In Fig. 5c we show monthly-averaged discharge at Lobith from the 0.5 and $0.05^{\circ} \mathrm{GHM}$, forced with EC-Earth T799, EC-Earth T159, and ERAI. Observed discharge is also shown. Figure 7 shows the discharge measures in a barplot.

The discharge simulated with ERAI forcing largely underestimates the observed discharge $\left(\sim 700 \mathrm{~m}^{3} \mathrm{~s}^{-1}\right)$, in particular from June until December (Figs. 7 and 5c). Photiadou et al. (2011) and Szczypta et al. (2012) present similar results, which they relate to an underestimation of precipitation in ERAI (Balsamo et al., 2010). However, our results show good estimates of basin-averaged precipitation from ERAI, except for a slight underestimation from August to November (Fig. 5a). Therefore, we conclude that the GHM is too dry in the summer months for the Rhine basin, introducing a negative bias in discharge. We also find lower discharges in the end of summer with EC-Earth forcing, possibly related to the dry bias of the GHM. From February until May, the overestimations in precipitation from both resolutions' GCMs are reflected in overestimations of discharge, with the largest bias for the low-resolution forcing (Fig. 5c and $\bar{Q}_{\text {max }}$ in Fig. 7).

For the discharge extremes, we show similar Gumbel plots to those for precipitation, now for annual maximum discharges per season (right panels in Fig. 6). The differences found in the return times of 10-day precipitation sums between the high- and low-resolution simulations are reflected in the differences found in the return values for the discharge, in every season. However, the differences between simulations and observations are not consistent from precipitation to discharge. Firstly, this is because the hydrological model has a large influence on the discharge results, which was already seen from the monthly-averaged discharge plots. For example, the dry bias of the model results in lower discharge extremes in SON (Fig. 6h). Secondly, there is no one-to-one correlation between precipitation sums and discharge, as is shown more extensively in the next Sect. 4.1.4. Lastly, the River Rhine is highly regulated, which affects the observations but not the simulations. 

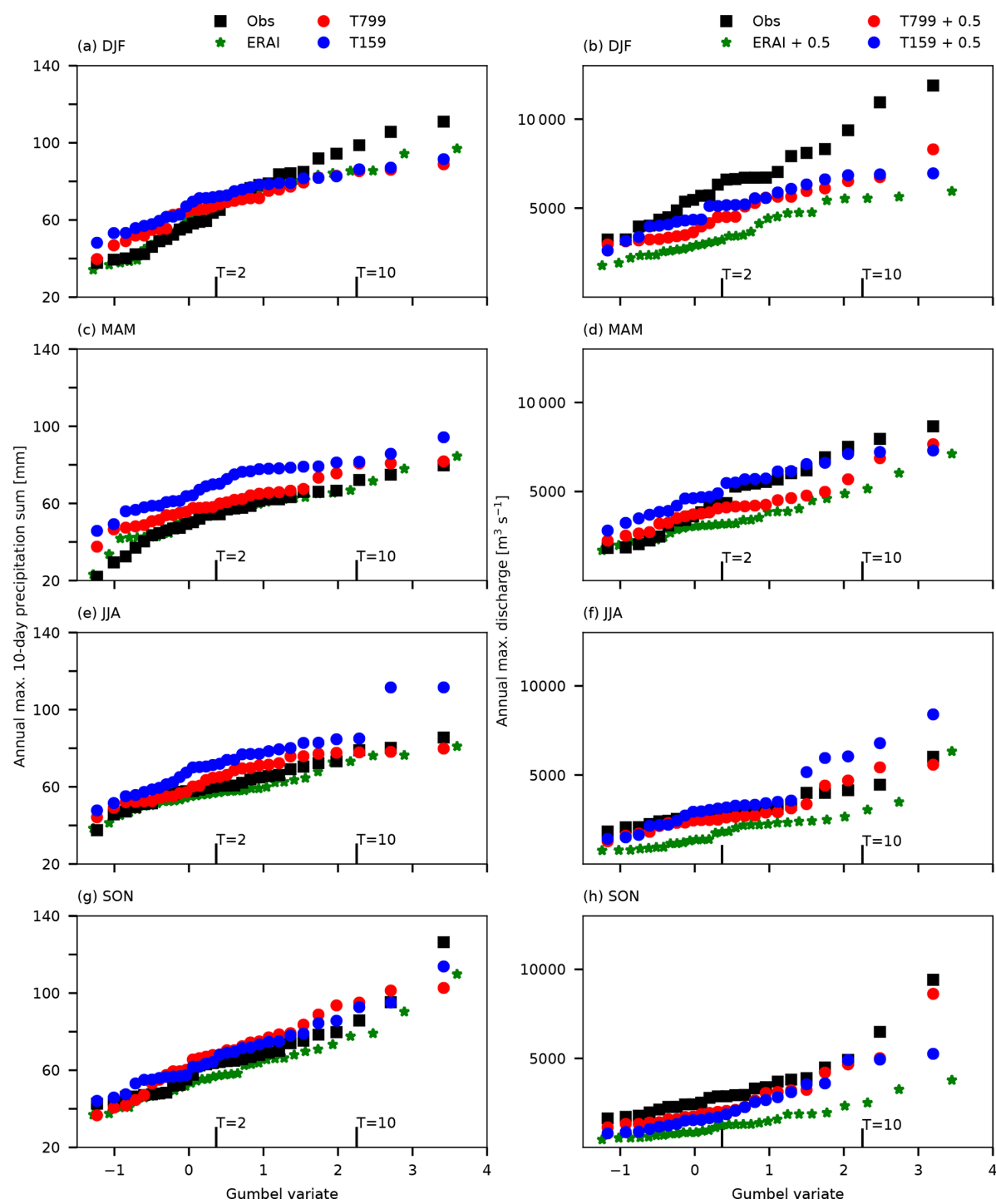

Figure 6. Gumbel plots of seasonal (DJF, MAM, JJA, and SON) maximum 10-day precipitation sums (mm) over the Rhine (a, c, e, g) and maximum discharge $\left(\mathrm{m}^{3} \mathrm{~s}^{-1}\right)$ at Lobith $(\mathbf{b}, \mathbf{d}, \mathbf{f}, \mathbf{h})$ and their related return times $T$ expressed in standardized Gumbel variate $x=$ $-\ln (-\ln (T)$ ). Observed discharges are shown in black, high-resolution forcing (T799) in red, low-resolution forcing (T159) in blue, and forcing with ERA-Interim in green. The discharge results are output from the $0.5^{\circ} \mathrm{GHM}$.

Overall, we can conclude that with the high-resolution ECEarth forcing the seasonal cycle and the monthly-averaged discharges are better represented compared to the lowresolution forcing, mainly because of improvements in precipitation. The difference in precipitation between the model resolutions is clearly reflected in discharge, although biases in the hydrological model also influence these results. The discharge extremes $\left(\bar{Q}_{\min }\right.$ and $\left.\bar{Q}_{\max }\right)$ are not consistently improved with high-resolution forcing. It is not clear from these analyses whether that is related to the forcing or to the performance of the hydrological model. The results are robust based on our modelling system.

We also tested the resolution sensitivity of the global hydrological model. We find small but not significant differ- ences in the discharge (measures) between the 0.5 and $0.05^{\circ}$ models; the high-resolution GHM $\left(0.05^{\circ}\right)$ gives slightly lower annual mean discharge results. With the $0.05^{\circ}$ model, the peak flows are less extreme and the low flows are similar to the low flows from the $0.5^{\circ}$ model. Because of a higherresolution orography, a more detailed river network is present in the high-resolution model. Due to the presence of extra tributaries the response of precipitation to the main river may be damped, leading to a decrease in the peak flow.

\subsubsection{Outlook on the extremes for the Rhine}

In previous sections, we showed that, compared to observations, the mean (monthly) statistics of precipitation, ac- 


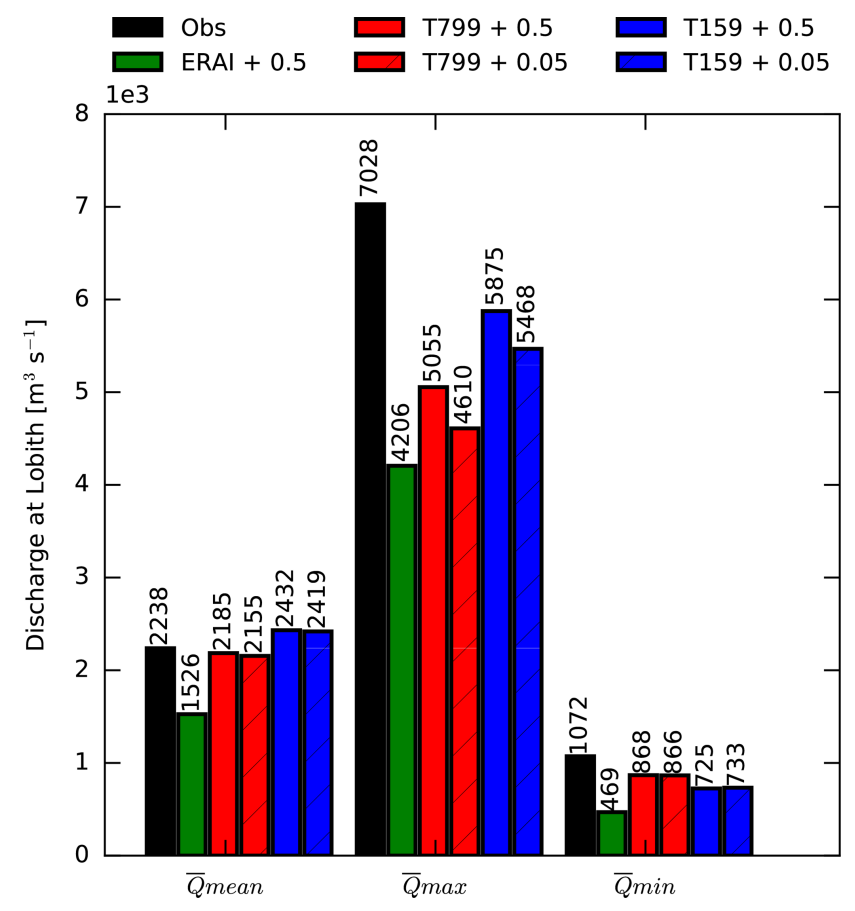

Figure 7. $\bar{Q}_{\text {mean }}, \bar{Q}_{\text {max }}$, and $\bar{Q}_{\min }$ in $\mathrm{m}^{3} \mathrm{~s}^{-1}$ at Lobith for the observations and the different combinations of simulations.

tual evaporation, and discharge are improved with highresolution modelling. We show the correlation between $10-$ day precipitation sums and daily discharge in Fig. 8. It should be noted that by applying a moving window over the 24-year time series, individual events are reflected in multiple subsequent data points. We find the highest correlations during winter and the lowest correlations during summer. In summer, more evaporation occurs, which decreases the correlation between precipitation and discharge. In winter, precipitation amounts are large and there is almost no evaporation, leading to higher discharges. In spring (MAM), fast surface runoff can be generated by rain occurring over saturated soils and rain-on-snow events (McCabe et al., 2007). We also find that the difference in correlations between the seasons is better represented in high resolution than low resolution, compared to observations (Fig. 8). In addition, the distribution of discharge and precipitation values of the high-resolution forcing compares better to observations. The low discharge values, which occur in JJA with the low-resolution forcing, can be related to two events in two members of the simulations, and are unrealistic. The correlations of precipitation and discharge from the high-resolution GHM are not shown here, as these distributions are similar to the distributions with the low-resolution GHM (Fig. 8a and b), except that less high peak flows are found with the higher-resolution model (Fig. 7).

To illustrate how the models simulate a high-impact event, we show here an event for the Rhine basin. The selected event is indicated with an open circle in Fig. $8 \mathrm{~b}$ and is an annual maximum in precipitation, occurring at the end of November. The average precipitation sum in SON is $30 \mathrm{~mm}$. In this case the sum is $103 \mathrm{~mm}$, resulting in a discharge of almost $9000 \mathrm{~m}^{3} \mathrm{~s}^{-1}$. Figure 9 a shows the rainfall-runoff distribution from 20 days before until 10 days after the selected event. In addition, the synoptic situation is shown with 10-dayaveraged mean sea level pressure, vertical integrated moisture fluxes, and the 10-day precipitation sums (Fig. 9b). From the mean sea level pressure and moisture fluxes, we can infer that there is a low-pressure system (mid-latitude cyclone) situated over the North Atlantic, before the coast of Norway, bringing moisture from the Atlantic over Europe leading to extreme precipitation over the Alps.

This single case is an example of the linkage between components in the hydrometeorological system; large-scale circulation associated with extreme precipitation and high discharges for the Rhine basin. In this case, the high-resolution GCM is able to simulate patterns that better correspond to observations. This does not mean that the low-resolution GCM is not able to simulate such circulation patterns, but previous studies have shown common biases among low-resolution GCMs, such as a too zonal storm track (Chang et al., 2012; Van Haren et al., 2015; Zappa et al., 2013).

\subsection{Mississippi}

\subsubsection{Precipitation in the Mississippi basin}

While precipitation over the Rhine is dominated by the storm track, the Mississippi basin has multiple climatic drivers (Fig. 2). Moisture is advected from the Pacific, resulting in high precipitation amounts over the Rocky Mountains (4$5 \mathrm{~mm} \mathrm{day}^{-1}$ ). The Great Plains, which are situated on the lee side of the Rockies, are relatively dry $\left(1-2 \mathrm{~mm} \mathrm{day}^{-1}\right)$, whereas the south-east of the USA is relatively wet (3$4 \mathrm{~mm} \mathrm{day}^{-1}$ ) because of convection and advection of moisture from the warm tropical Caribbean and Gulf of Mexico. Figure 10 shows the distribution of seasonal-averaged precipitation over the Mississippi basin for the two resolutions of the GCM and the observations (CPC). There are clear improvements in the distribution of precipitation for the high-resolution GCM over mountain ranges attributed to better representation of orography, such as over the Rockies, the Cascades, and the Sierra Nevada, which is in line with previous resolution studies with an atmosphere-only GCM (Duffy et al., 2003) and a coupled ocean-atmosphere GCM (van der Wiel et al., 2016). Comparison of the simulations with observations reveals an overestimation of precipitation in the north-east of the catchment in DJF and MAM (Fig. 10). In SON, in the south of the Mississippi basin, the high-resolution model shows higher precipitation amounts, comparable to the observations. These are not found in the low-resolution model. This could possibly indicate that cyclones which bring precipitation along the coast are better captured in the high-resolution model. 

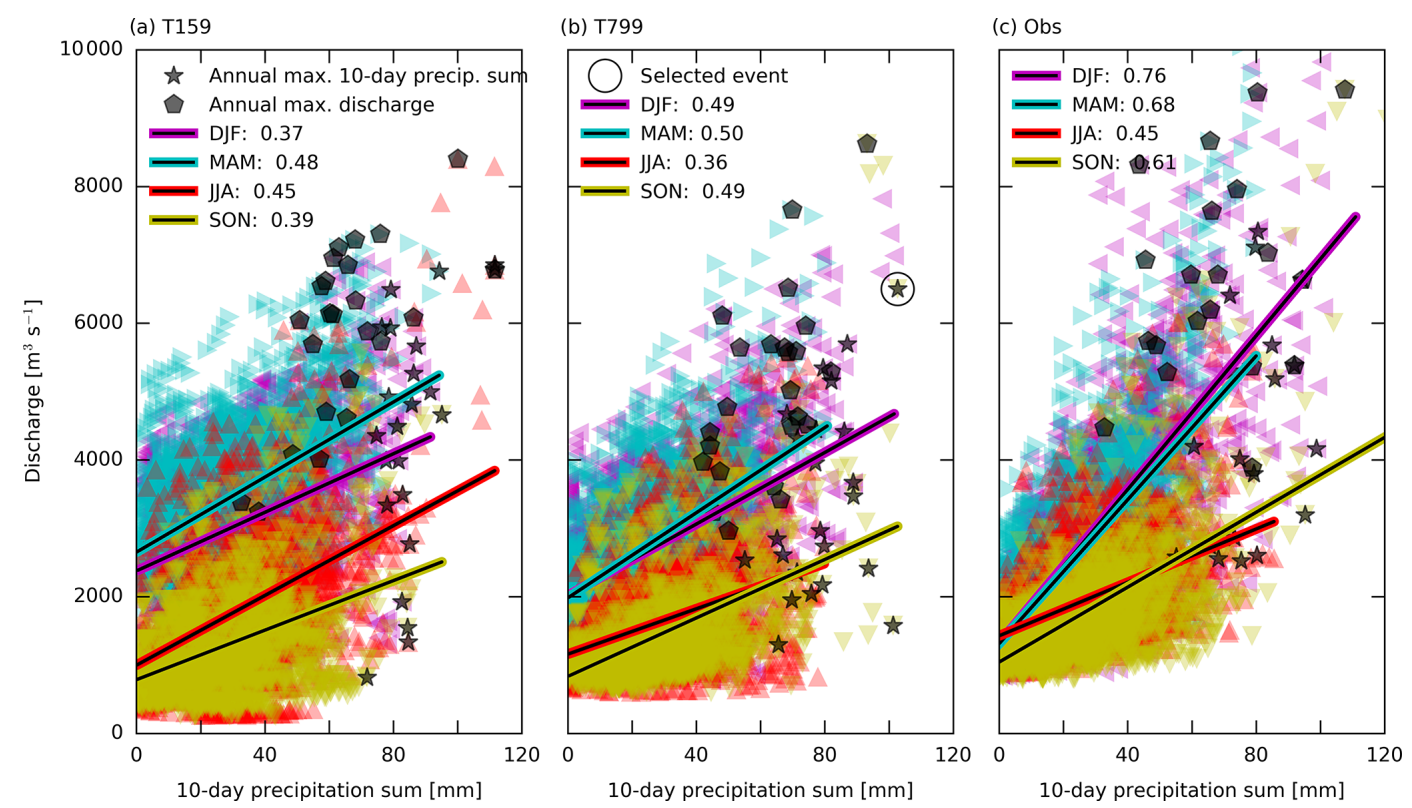

Figure 8. Scatterplot for the Rhine basin of daily discharge $\left(\mathrm{m}^{3} \mathrm{~s}^{-1}\right)$ with previous 10-day precipitation sums (mm) for (a) the low-resolution forcing (T159), (b) the high-resolution forcing (T799), and (c) the observations (Obs.). The discharge results shown here are obtained with the $0.5^{\circ} \mathrm{GHM}$. The different seasons are indicated with the colours and regression line and correlation value. The annual maxima of both 10-day precipitation sums and discharge are indicated with respectively the black stars and hexagons.
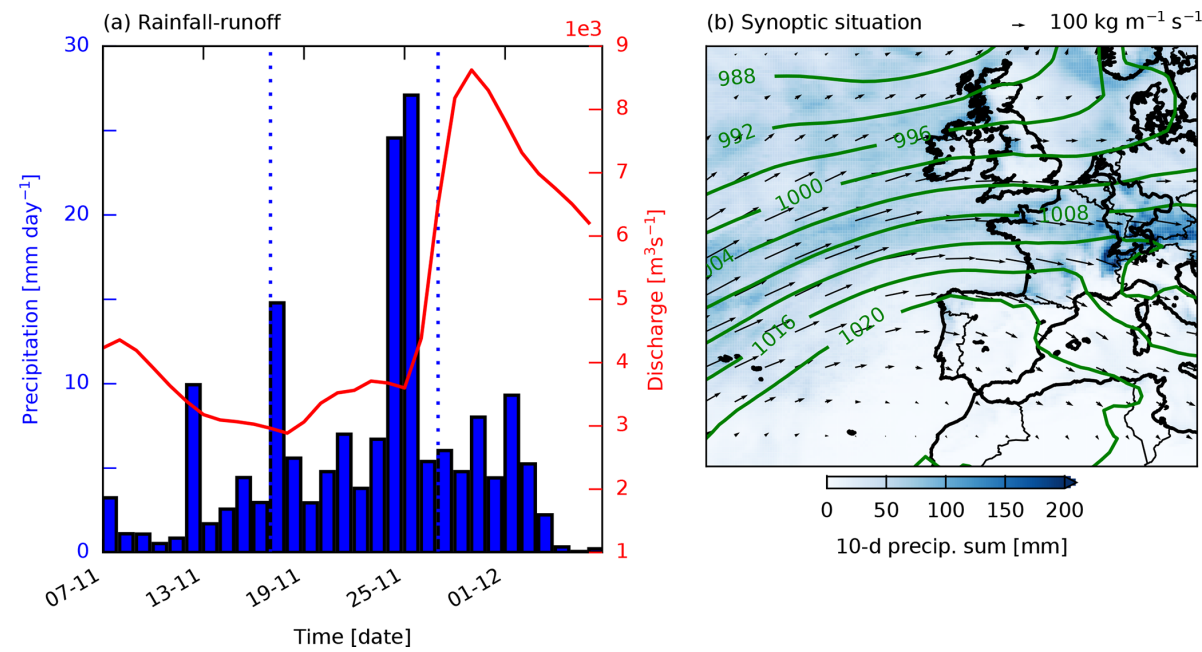

Figure 9. In (a) precipitation (in blue) and discharge (in red) for the Rhine are shown 20 days before and 10 days after the selected event. The vertical dotted lines indicate the 10-day period, which is spatially summed in (b). The contour lines in (b) indicate the 10-day-averaged mean sea level pressure in $\mathrm{hPa}$ and the arrows the 10-day-averaged vertical integrated moisture fluxes in $\mathrm{kg} \mathrm{m}^{-1} \mathrm{~s}^{-1}$.

Monthly- and basin-averaged daily precipitation sums of both simulations show a shift of 1 to 2 months in the seasonal cycle, where the highest monthly values occur in April/May instead of in June (Fig. 11a). Moreover, the amount of precipitation in this shifted peak is overestimated (Fig. 11a). The increase in precipitation in October-November is not observed, but occurs, most pronounced, in the high-resolution simulations. A similar peak in October-November is found in the convective part and suggests a bias in convection in the high- resolution model. Similar precipitation biases are found in the EC-Earth simulations for the sub-basin averages (Missouri and Arkansas-Red, not shown). In contrast to the ECEarth simulations, precipitation from ERAI shows the correct seasonal cycle (Fig. 11a). EC-Earth and ERAI are based on the same atmospheric model (IFS), albeit different versions. Therefore we hypothesize that the precipitation bias found with EC-Earth is not present in the ERAI reanalysis, because of the data assimilation process. The precipitation 
(a) T159 DJF

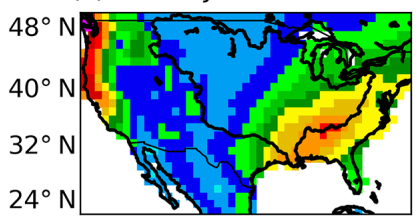

(d) T159 MAM

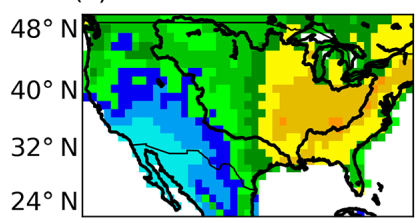

(g) T159 JJA

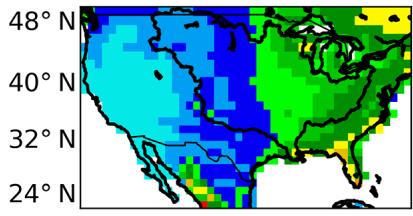

(j) T159 SON

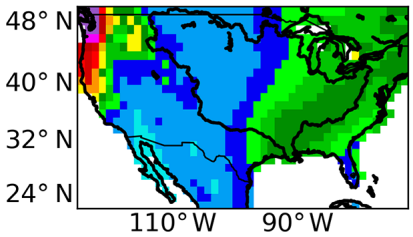

(b) T799 DJF

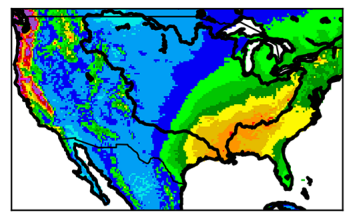

(e) T799 MAM

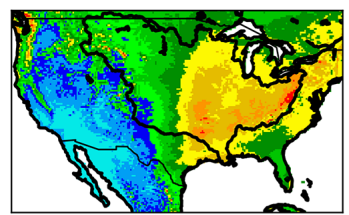

(h) T799 JJA

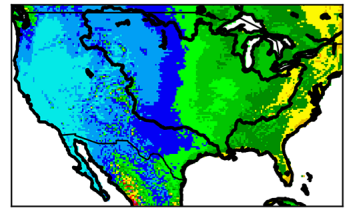

(k) T799 SON

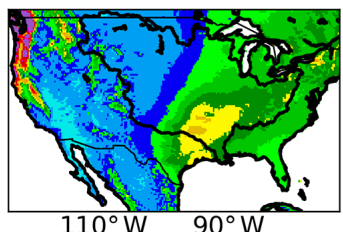

(c) CPC DJF

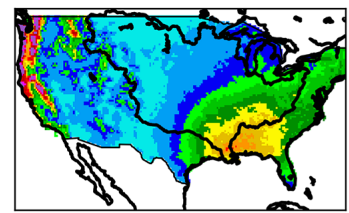

(f) CPC MAM

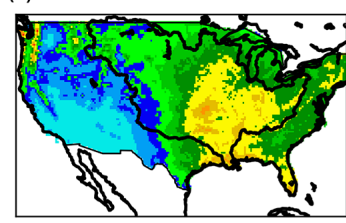

(i) CPC JJA

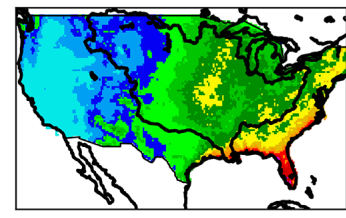

(I) CPC SON

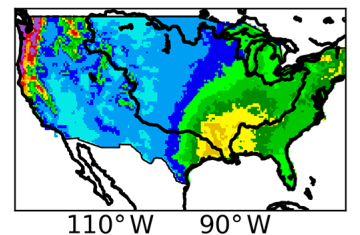

Figure 10. Seasonal means (DJF, MAM, JJA, and SON) of daily precipitation sums $\left(\mathrm{mm} \mathrm{day}^{-1}\right)$ from the low-resolution EC-Earth simulations (T159, a, d, g, j), the high-resolution EC-Earth simulations (T799, b, e, h, k), and the observations (CPC, $, \mathbf{f}, \mathbf{i}, \mathbf{l})$.

budget from the ERA20C reanalysis data, where assimilation is performed on fewer variables than ERAI, shows a larger bias with observations compared to ERAI, supporting our hypothesis (ERA20C data not shown).

Apart from the precipitation bias between EC-Earth simulations and observations, no substantial differences in basinaveraged precipitation between the low- and high-resolution simulations were found (Fig. 11a). This similarity of the high- and low-resolution GCM could be explained by the convective component of precipitation, which is modelled at the sub-grid scale (i.e. parameterized) for both resolutions. We will further discuss convection in the next Sect. 4.2.2. Thereby, we will also assess the sensitivity of resolution to the large-scale circulation over the Mississippi basin.

The bias between observations and simulations is also reflected in the Gumbel plots of 10-day precipitation sums per season over the basin (left panels of Fig. 12). In MAM, there is an overestimation of the extremes for all the return times and in JJA an underestimation for all the return times. In $\mathrm{SON}$, there are much larger precipitation extremes in the high resolution compared to the low resolution (Fig. 12g). This could possibly be related to the improved simulation of tropical cyclones with higher resolution, although this should be investigated further. In DJF, we find larger biases with the high resolution compared to the low resolution, although previous studies show improvements of extreme precipitation with increased resolution (Iorio et al., 2004; Wehner et al., 2010; van der Wiel et al., 2016; Duffy et al., 2003). In the winter season moisture advection from the Pacific plays a large role. A more detailed orography in the high-resolution simulations could trigger more precipitation leading to overestimations. In addition, "observed" precipitation products, like the CPC dataset, severely underestimate precipitation over the western mountain ranges (Lundquist et al., 2015; Henn et al., 2017).

\subsubsection{Resolution analysis of the Mississippi basin}

In the previous Sect. 4.2.1, our results show that a bias exists between simulated and observed basin-averaged precipitation for the Mississippi, especially in MAM $(\sim 0.5$ $1 \mathrm{~mm} \mathrm{day}^{-1}$, Fig. 11a). Moreover, no substantial differences in precipitation are found between the low- and highresolution simulations, except for SON (Fig. 11a). This is in contrast with our results for the Rhine basin, where better precipitation estimates are found with the high-resolution 

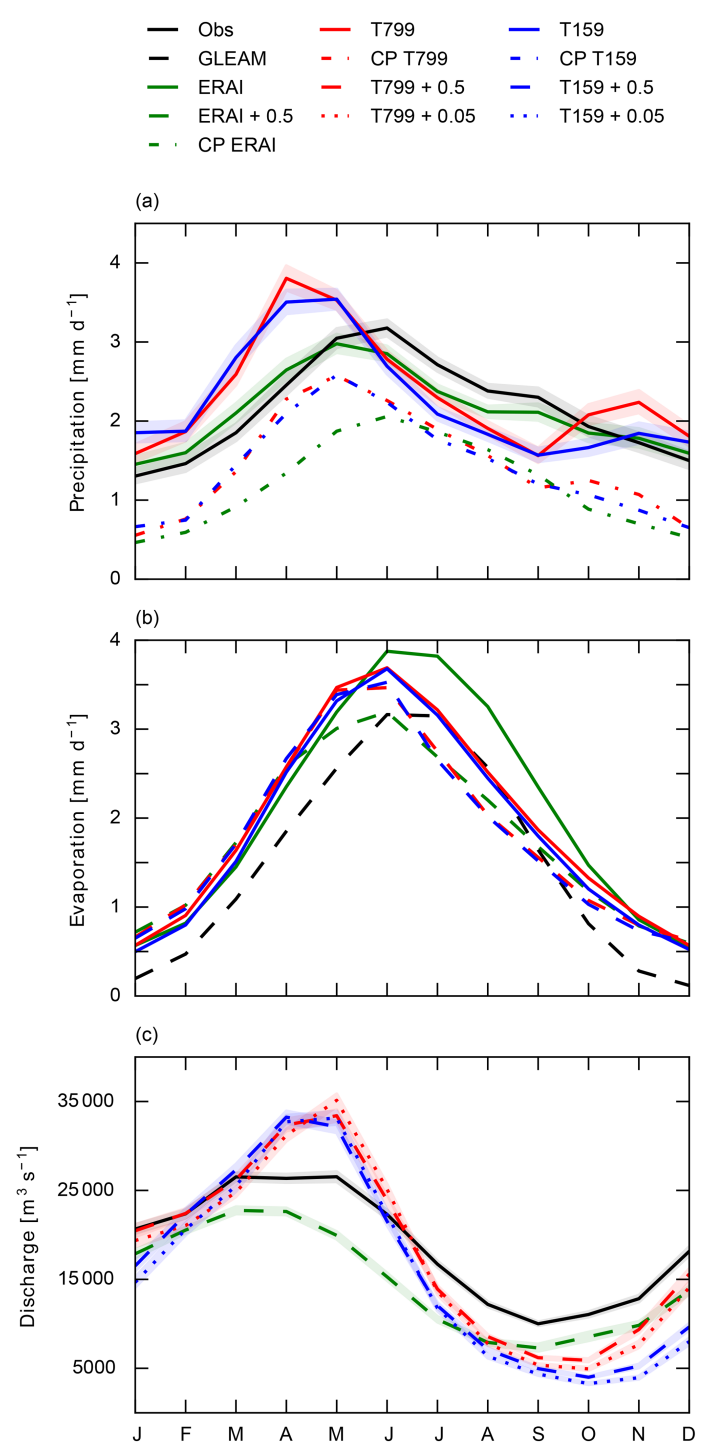

Figure 11. Monthly averages of (a) basin-averaged daily precipitation sums (mm day $\left.{ }^{-1}\right)$, (b) basin-averaged daily evaporation sums $\left(\mathrm{mm} \mathrm{day}^{-1}\right)$, and (c) daily discharge $\left(\mathrm{m}^{3} \mathrm{~s}^{-1}\right)$ at Vicksburg for the Mississippi basin. Black lines are observations; green is ERAI. The red and blue lines are respectively the high-resolution (T799) and low-resolution (T159) GCMs. The dash-dotted lines indicate convective precipitation, dashed lines output from the $0.5^{\circ} \mathrm{GHM}$, and dotted lines output from the $0.05^{\circ} \mathrm{GHM}$. The shaded bands indicate the $95 \%$ confidence intervals.

GCM, because of better resolved large-scale circulation patterns (Van Haren et al., 2015). Here, we will shortly assess the resolution sensitivity of large-scale circulation and the role of convection over the Mississippi basin.

We show the precipitation generated by the convective parameterization as monthly averages in Fig. 11a. The monthly averages of convective precipitation are very similar for the low- and high-resolution GCM. Convective precipitation from ERAI shows a different seasonal cycle, with a peak later in the season (Fig. 11a). This suggests that the bias in total precipitation in EC-Earth is mainly related to a bias in convective precipitation. The large contribution of convective precipitation to total precipitation in the model likely explains why we do not find differences in basin-averaged precipitation between the two resolutions in MAM and summer (Fig. 11a), as convective cloud systems are smaller than both model resolutions' grid size and therefore parameterized. This is confirmed by Iorio et al. (2004), who found no improvements in precipitation over the USA in MAM and JJA with increased resolution, which was related to the dominance of convective precipitation in these two seasons. Balsamo et al. (2010) mentioned that large-scale weather systems in winter are easier to simulate in numerical weather predictions than convective systems in summer. There are also studies which show that the link between soil moisture and precipitation is incorrect in models that parameterize convection (Hohenegger et al., 2009; C. M. Taylor et al., 201a). Recently, convection-permitting simulations over the USA were performed (Liu et al., 2017), which show good performance in capturing the seasonal precipitation climatology, except for a dry bias in summer. In addition, the main characteristics of mesoscale convective systems were well captured in these new simulations (Prein et al., 2017).

Besides convection, large-scale structures bring moisture from the Pacific over the Rockies and from the Caribbean and Gulf of Mexico with the low level jet to the Mississippi. The resolution dependency of these large-scale processes is assessed by analysing geopotential height at $500 \mathrm{hPa}$ (data not shown) and $850 \mathrm{hPa}$ (Fig. 13). We find that these patterns are very similar between EC-Earth T799, EC-Earth T159, and ERAI. In addition, we also show moisture convergence, as defined under steady state: $P-E=-\frac{1}{g} \nabla \cdot \int_{0}^{p_{\mathrm{s}}}(V q) \mathrm{d} p$, where $P$ is precipitation, $E$ is evaporation, $g$ is the gravitational constant, $V$ represents the horizontal wind components, and $q$ is specific humidity. We define moisture convergence positively and derive it from evaporation and precipitation. The overall patterns of moisture convergence are similar for ECEarth T799, EC-Earth T159, and ERAI. Differences on the local scale can be related to differences in resolution and therefore the representation of orography. From the difference plots (Fig. 13d and e) we find that the moisture convergence is more similar between the high- and low-resolution EC-Earth than between the high-resolution EC-Earth and ERAI. This is in line with the precipitation patterns we found (Fig. 11a), which are similar between the two resolutions but quite different in ERAI. There is more convergence in the high-resolution GCM compared to ERAI, which also results in more precipitation in the high-resolution GCM. There is also slightly more convergence in the high-resolution ECEarth compared to the low resolution, and we also found slightly higher monthly-averaged precipitation in SON. 

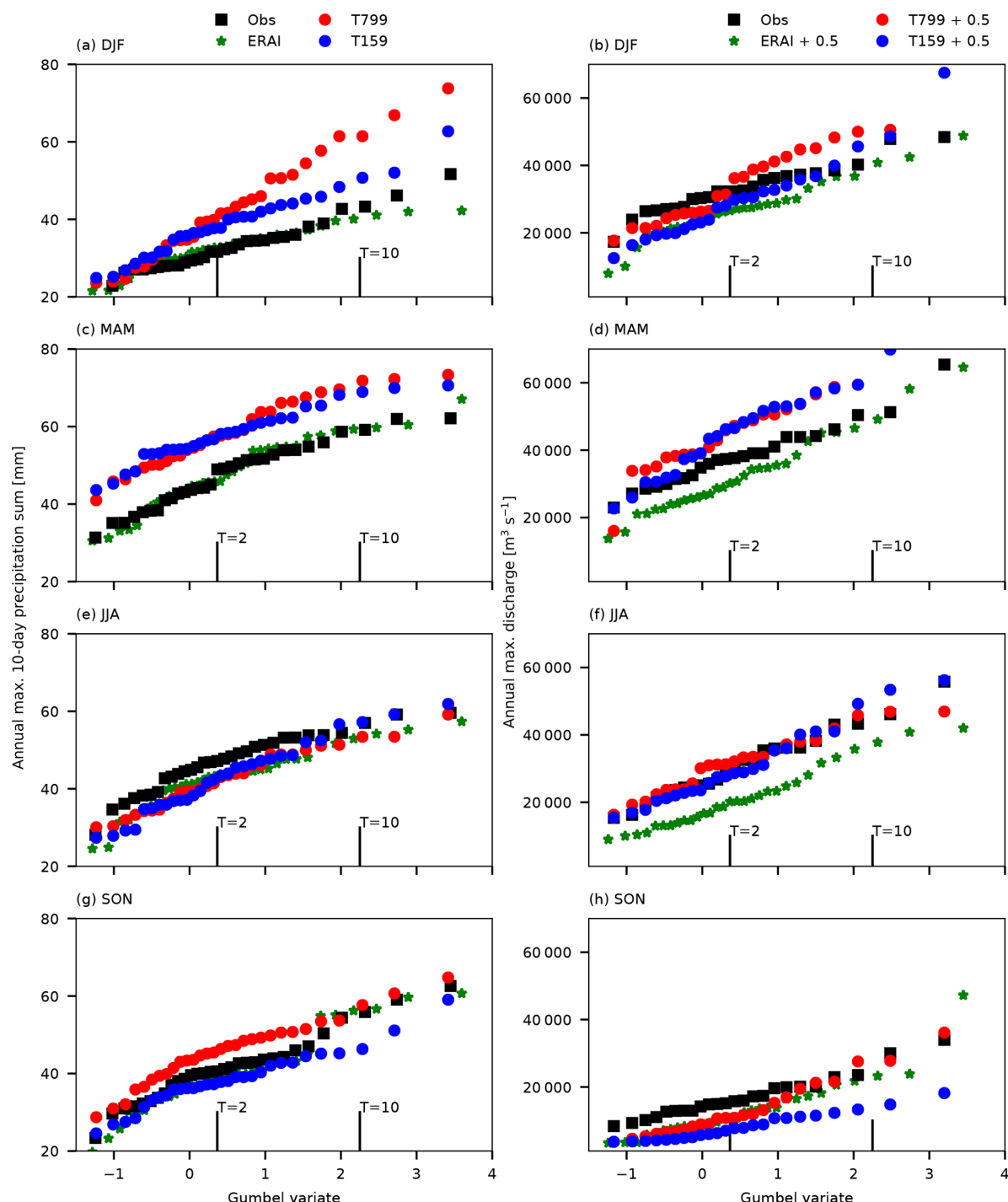

Figure 12. Gumbel plots of seasonal (DJF, MAM, JJA, and SON) maximum 10-day precipitation sums (mm) over the Mississippi (a, c, $\mathbf{e}, \mathbf{g})$ and maximum discharge $\left(\mathrm{m}^{3} \mathrm{~s}^{-1}\right)$ at Vicksburg $(\mathbf{b}, \mathbf{d}, \mathbf{f}, \mathbf{h})$ and their related return times $T$ expressed in standardized Gumbel variate $x=-\ln (-\ln (T))$. Observed discharges are shown in black, high-resolution forcing (T799) in red, low-resolution forcing (T159) in blue, and forcing with ERA-Interim in green. The discharge results are output from the $0.5^{\circ} \mathrm{GHM}$.

To summarize, this resolution analysis suggests that the positive bias in precipitation in EC-Earth is mainly related to the convective part of precipitation. A first analysis of the geopotential fields $(500$ and $850 \mathrm{hPa})$ shows that the largescale patterns are very similar between the resolutions of EC-Earth and ERAI. We do find that the difference in moisture convergence between both simulations of the GCM is smaller than between the GCMs and ERAI. This possibly indicates that the triggering of convection is different between the GCM and ERAI. However, we recommend further analysis to confirm these results.

\subsubsection{Actual evaporation in the Mississippi basin}

A consistent pattern between evaporation and precipitation is found in the simulations for the Mississippi basin. The shift in seasonal cycle in the EC-Earth precipitation budget is reflected in a similar shift in the $E_{\text {act }}$ budget (Fig. 11b). Furthermore, there are no substantial differences found in $E_{\text {act }}$ between the two resolutions of the GCM. Nevertheless, we find large overestimations $\left(\sim 0.5 \mathrm{~mm} \mathrm{day}^{-1}\right)$ of $E_{\text {act }}$ in winter (NDJF) in the simulations compared to the GLEAM dataset. In November and December, these overestimations can not be related to the precipitation budget. These high amounts of evaporation in winter are also found for the 

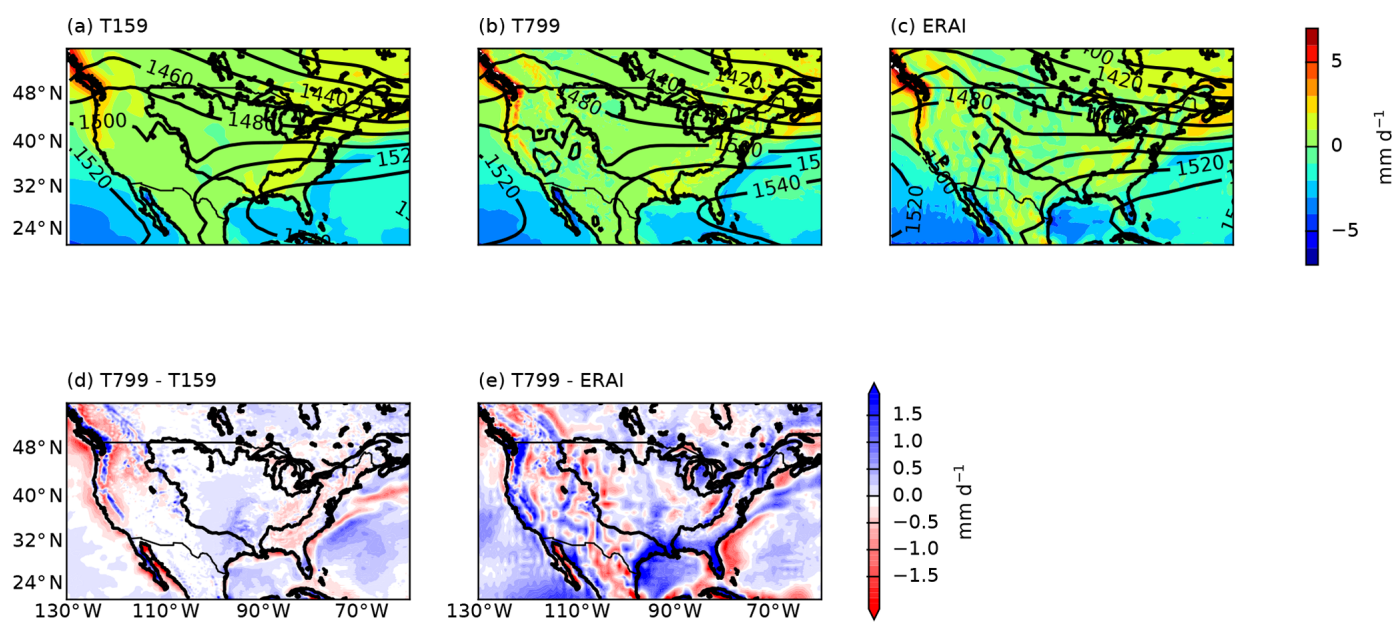

Figure 13. 30-year averages of geopotential height $(\mathrm{m})$ at $850 \mathrm{hPa}$ in contour lines and moisture convergence $\left(\mathrm{mm} \mathrm{day}^{-1}\right)$ in colour over the Mississippi basin for (a) the low-resolution GCM (T159), (b) the high-resolution GCM (T799), (c) ERAI, and the difference between (d) high- and low-resolution GCMs (T799-T159) and (e) the high-resolution GCM and ERAI (T799-ERAI).

Rhine and are therefore possibly related to the performance of the GHM.

The largest overestimations of actual evaporation are from the ERAI data, which was also shown by Betts et al. (2009). The land-surface scheme of ERAI (TESSEL) has a fixed leaf area index (van den Hurk et al., 2003) and a global uniform soil texture leading to low amounts of surface runoff (Balsamo et al., 2009), which could induce smaller amounts of interception and open water evaporation resulting in overestimations of evaporation. Moreover, there are large differences in actual evaporation from ERAI directly and from the GHM forced with ERAI (Fig. 11b). These differences are larger for ERAI than for EC-Earth, which was also observed for the Rhine basin.

The actual evaporation from the GHM decreases faster from June onwards compared to the actual evaporation from the GCM. A similar sudden decrease was found in the discharge at Vicksburg. In other words, there occurs a quick drying in the GHM from May to June. This should be mainly related to the vegetation and soil characteristics of the GHM, as the GCM does not show the quick drying. Overall, it is hard to judge whether the evaporation product from the GCM or the GHM performs better in comparison with the observations as the seasonal bias in precipitation also influences the evaporation budget.

\subsubsection{Discharge in the Mississippi}

We show the monthly-averaged discharge at Vicksburg in Fig. 11c and the different discharge measures in Fig. 14. We find an underestimation of the ERAI-forced discharge during the whole year compared to the observed discharge. We can only partly explain this with the underestimation of ERAI precipitation in JJA (Fig. 11a). Precipitation from the ERAI/Land product agrees very well with the observations;

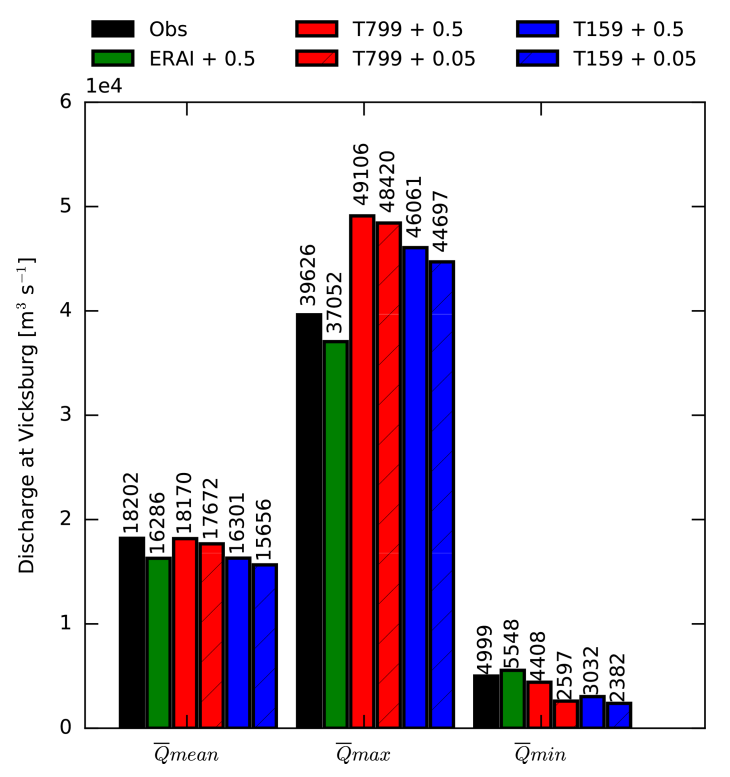

Figure 14. $\bar{Q}_{\text {mean }}, \bar{Q}_{\text {max }}$, and $\bar{Q}_{\text {min }}$ in $\mathrm{m}^{3} \mathrm{~s}^{-1}$ at Vicksburg for the observations and the different combinations of simulations.

however, discharge is still underestimated (data not shown). Therefore, we conclude that most of the underestimation in discharge is related to an overestimation of actual evaporation, which was shown in Sect. 4.2.3.

Annual mean discharge is underestimated $(\sim$ $2000 \mathrm{~m}^{3} \mathrm{~s}^{-1}$ ) with the low-resolution forcing and well simulated with the high-resolution forcing $\left(\bar{Q}_{\text {mean }}\right.$ in Fig. 14). The monthly-averaged discharge forced with ECEarth is too high in spring, because of too high precipitation values (Fig. 11). In January and February, precipitation (including snow) is also overestimated in EC-Earth, leading to increased discharges in April and May when the temperature 

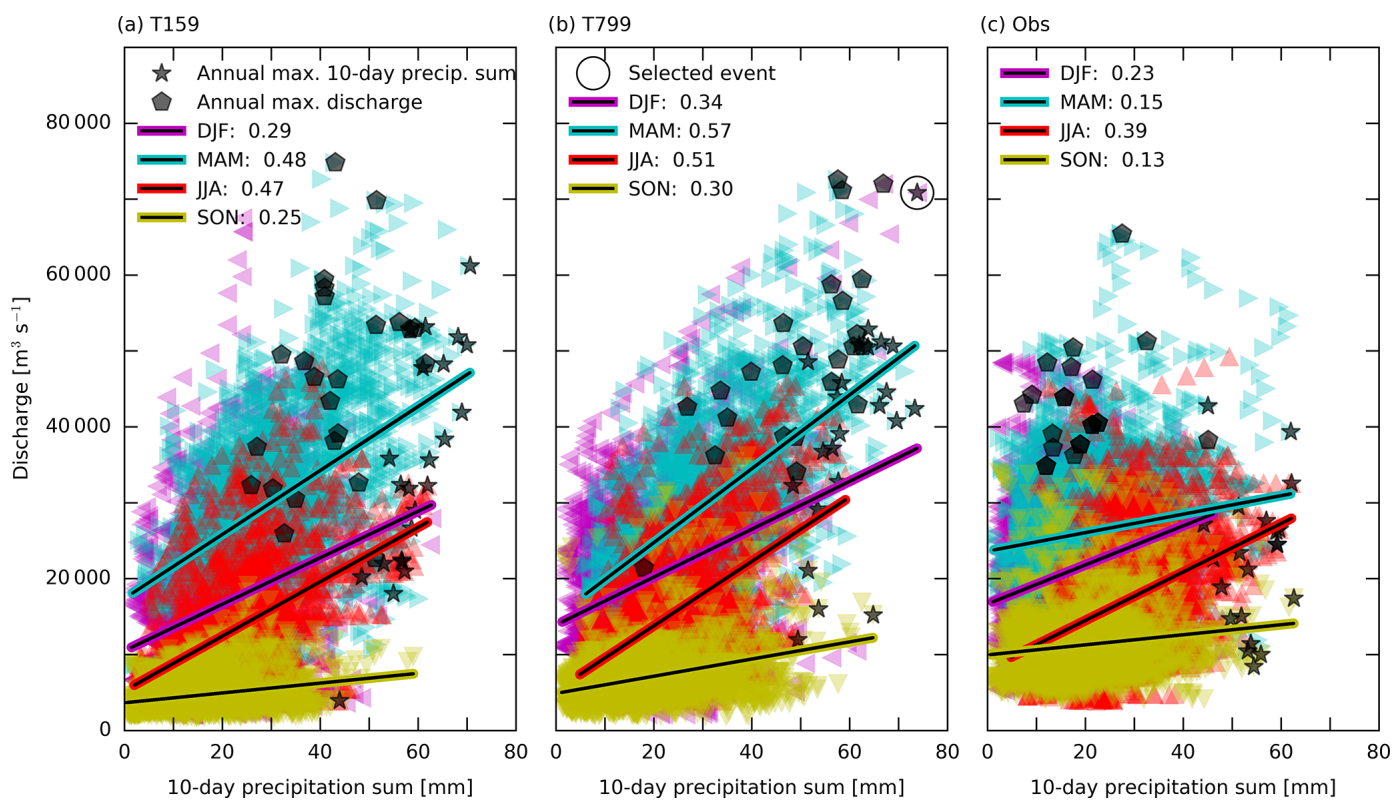

Figure 15. Scatterplot for the Mississippi basin of daily discharge $\left(\mathrm{m}^{3} \mathrm{~s}^{-1}\right)$ with previous 10-day precipitation sums (mm) for (a) the lowresolution forcing (T159), (b) the high-resolution forcing (T799), and (c) the observations (Obs). The discharge results shown here are obtained with the $0.5^{\circ} \mathrm{GHM}$. The different seasons are indicated with the colours and regression line and correlation value. The annual maxima of both 10-day precipitation sums and discharge are indicated with respectively the black stars and hexagons.

rises. From May onwards the discharge decreases more rapidly in the model than observed. During the rest of the year, there is a clear discharge response to the precipitation budget. It is possible that in October-November the improvements in discharge for the high resolution exist for the wrong reason, as the second precipitation peak in the high resolution is not seen in the observations.

For the extremes in SON, we also find a clear difference between the high- and low-resolution forcing (Fig. 12g and $\mathrm{h}$ ). With high-resolution forcing larger extremes are found, although discharge is still underestimated for lower return values, which was also found for the monthly averages. In DJF, there is a clear difference between the two resolutions for the largest return values in precipitation, and this is also reflected in the return values for discharge, which are larger with high-resolution forcing. In MAM, precipitation (extremes) is largely overestimated in EC-Earth, which is reflected in slight overestimations of discharge in the lower return values but large overestimations for the higher return values (Fig. 12c and d). As the GHM does not take into account reservoirs, a faster response of discharge on precipitation in the model simulations is expected compared to the observations. In the summer months (JJA), the discharge extremes are quite well represented by the model. Nevertheless, the ERAI-forced discharge underestimates the extremes in these months.

In general, for the monthly averages and lower return values, the dry bias of the GHM is clearly reflected in the results. For the extremes with higher return values, we find that the signal of the precipitation extremes is reflected in the discharge extremes and the model performance plays a less important role. There are no substantial differences in discharge between the 0.5 and $0.05^{\circ}$ resolutions, as was also found for the Rhine.

\subsubsection{Outlook on the extremes for the Mississippi}

Figure 15 shows the correlations between 10-day precipitation sums and discharge for both resolution simulations and the observations over the Mississippi basin. For the simulations (Fig. 15a and b), we find the highest correlations in summer and the lowest correlations in winter, which is similar to what we found for the Rhine basin. For every season, correlations are lower with the observations compared to the simulations, especially in MAM. As this is the cropping period, irrigation requires a lot of water and reduces substantially the observed streamflow. Irrigation is currently not included in the hydrological model. This result shows the importance of including human activities in hydrological models.

The selected event over the Mississippi basin (open circle, Fig. 15b) occurs in January and corresponds to both an annual maximum in the 10-day precipitation sum $(66.8 \mathrm{~mm})$ as well to an annual maximum in discharge $\left(72000 \mathrm{~m}^{3} \mathrm{~s}^{-1}\right)$. In addition, the selected event is the second most extreme event in the DJF Gumbel plot for precipitation (Fig. 12a). From the synoptic situation and the vertical integrated moisture fluxes in Fig. 16b we conclude that moisture is mainly transported from the Pacific and the Gulf of Mexico, leading to precipi- 


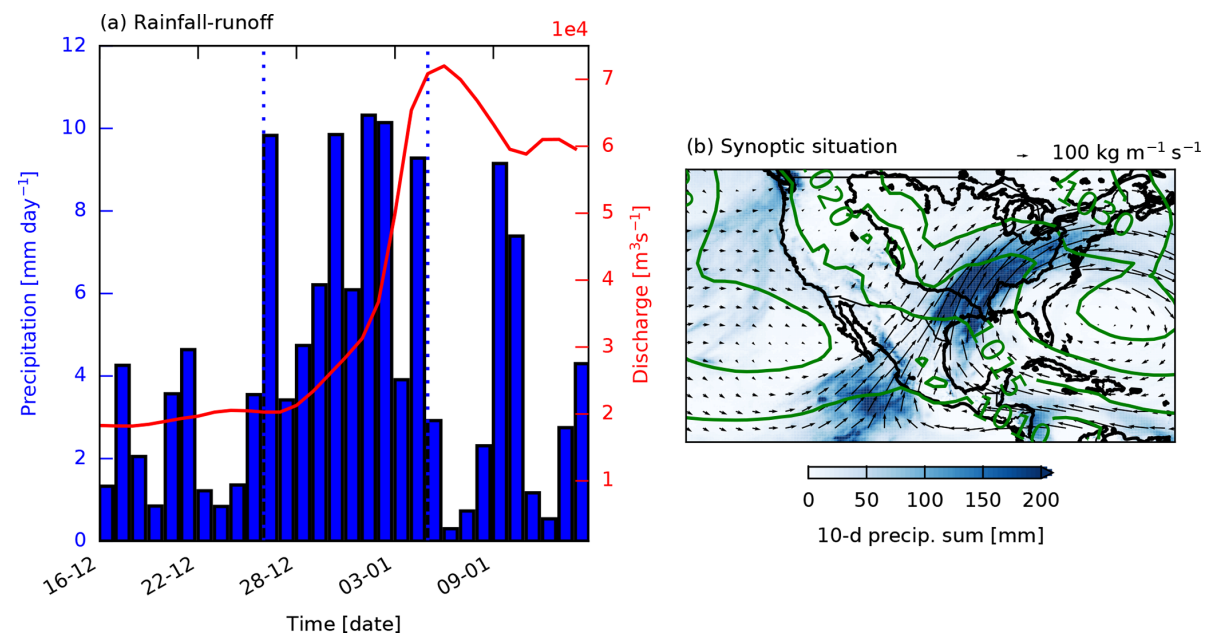

Figure 16. In (a) precipitation (in blue) and discharge (in red) for the Mississippi are shown 20 days before and 10 days after the selected event. The vertical dotted lines indicate the 10-day period, which is spatially summed in (b). The contour lines in (b) indicate the 10-day average mean sea level pressure in $\mathrm{hPa}$ and the arrows the 10-day averaged vertical integrated moisture fluxes in $\mathrm{kg} \mathrm{m}^{-1} \mathrm{~s}^{-1}$.

tation over the south-east of the Mississippi basin, which is a region prone to extreme precipitation (Wehner et al., 2010). Berghuijs et al. (2016) show that (multiple) large precipitation events mainly occur over the south-east of the USA during winter. As the precipitation falls very close to Vicksburg, the response in discharge is relatively quick and leads to an exceptionally high discharge $\left(72000 \mathrm{~m}^{3} \mathrm{~s}^{-1}\right)$, with a return period of 30 years.

\section{Discussion}

In this study, we have used the EC-Earth GCM to force the W3RA GHM, in order to investigate the benefits of spatial resolution increase, without modification to the process representation within the models. Due to the large computational costs and the large amount of data involved, our study is constrained to one combination of a GCM and GHM each run at two resolutions (Fig. 1), for two river basins: the Rhine and Mississippi. In this section, we evaluate our experiment and put our approach and results in perspective compared to other work and initiatives. We will discuss (i) the importance of GCM resolution in the context of other studies, (ii) the relevance of resolution increase in the GHM in comparison to a better process representation and the choice for using a global hydrological model instead of catchment-calibrated models, and (iii) the extrapolation of the results for our two basins to the global scale and the limitations thereof.

\subsection{Increased resolution of the global climate model}

We examined the effect of increased resolution on precipitation using an atmosphere-only set-up of the EC-Earth global climate model. By comparing two different resolutions with the same process representation, we were able to estimate the benefits of increased spatial resolution alone. As the spatial scales of atmospheric motions span the entire range from the global to the viscous scales, a resolution increase will always reveal more detailed flow characteristics. This is because the flow characteristics of a non-linear dynamical system such as the atmosphere will change when numerical resolution increases and viscosity and diffusivity decrease. Hence, we found that a resolution increase led to better precipitation simulations in the Rhine basin (Sect. 4.1.1), where precipitation is dominated by large-scale weather systems.

There are currently only a few global climate model simulations available at such high resolution as the EC-Earth T799 runs used in this study (Davini et al., 2017b; Delworth et al., 2012; Schiemann et al., 2018; and more references within Haarsma et al., 2016). Other global modelling experiments at high resolution similar to ours, such as Schiemann et al. (2018), who used a resolution of $\sim 25 \mathrm{~km}$ with the HadGEM model, also found improved winter precipitation over Europe. While we found that better representation of weather systems was the main driver of the improvement (Van Haren et al., 2015), they attributed the improvement mainly to a better resolved orography. The varying response to resolution increase among GCMs is one of the main themes of the HighResMIP project, where the robustness of climate simulations at high resolution $(\sim 25 \mathrm{~km})$ is examined (Haarsma et al., 2016). While this model intercomparison will likely reveal many new insights into the robustness of numerical model simulations, the studied models will still have insufficient resolution to capture all relevant atmospheric processes, such as convective precipitation and flow phenomena driven by small-scale orography. Hence further studies on the effect of resolution increases will be needed. 


\subsection{Process presentation versus increased resolution of the global hydrological model}

While for an atmospheric numerical model the main benefit of a horizontal resolution increase is the better representation of flow phenomena, such as weather systems, the main benefit of the GHM is found in the representation of details at the land surface, i.e. improved spatial heterogeneities in topography, soil, and vegetation. For this reason, to simulate the land-surface hydrology, we have chosen to calculate actual evaporation with the higher-resolution GHM rather than the GCMs' land-surface model (LSM). Besides, most GCMs (including EC-Earth) do not have a detailed routing module.

In a GHM, all processes are parameterized. No new phenomena are simulated by just increasing resolution. Increasing the resolution of a GHM potentially requires the addition of different process representations (and thus parameterizations) that become more relevant at finer resolution, such as lateral groundwater flow (Wood et al., 2011; Bierkens et al., 2015; Van Dijk, 2010a). Next to the potential need for additional processes to be included, acquiring the necessary parameters to run the GHM becomes increasingly complex at high spatial resolution. Many parameters are uncertain, especially because most are non-physical and difficult to determine across scales (Melsen et al., 2016).

Different approaches are taken to develop models that are robust over a range of spatial scales for the application in global hydrological modelling. For example, several studies apply parameter regionalization techniques to adapt parameters across scales (Samaniego et al., 2010). Gao et al. (2016, 2014a) suggest that, when physical processes are connected to the correct landscape indicators, regionalization can be applied without further calibration. The root-zone storage capacity is such a scale-independent parameter (Gao et al., 2014b). This approach has a potential for resolution comparison studies, and it can be applied globally (Wang-Erlandsson et al., 2016).

We believe that different approaches to deal with scale interactions, among the ones we mention here, deserve rigorous study. In this study, we followed probably the most simple approach, namely testing from a "global modelling perspective" if enhancing the resolution of the GHM will improve modelled discharge (going from 0.5 to $0.05^{\circ}$ ). We simply remapped the parameters from the low 0.5 to the high $0.05^{\circ}$ resolution model, except for vegetation and orography which are known at high resolution (see Sect. 3.2). This allows comparison of the outcome of the models in a transparent way, which would not be possible or be very difficult otherwise, because the model itself would change. With this technique, we find no consistent improvements in discharge with the higher-resolution GHM. This could be related to the choice of our GHM, as we only use one model, or to the need for more elaborated process representation (e.g. subsurface lateral flow). Our results therefore indicate that only increasing the resolution of the GHM has a limited effect on simulating discharge. This conclusion is in line with the achievements/challenges of prediction in ungauged basins as summarized in Hrachowitz et al. (2013).

Besides the discussion on process presentation versus high-resolution modelling, we would like to note that we have performed the simulations with W3RA from the viewpoint of "global hydrology", i.e. using a global hydrological model not specifically designed for the two basins. Often global hydrological models are used in a climate context while not being optimized for individual basins. If we want to obtain the best results in modelling the hydrological balance over the Rhine and Mississippi basins, we should have chosen specific regional calibrated models built for the specific basins (calibrated-catchment models), which is not in line with our viewpoint here.

Furthermore, we have only carried out a limited performance analysis of W3RA. The study by Beck et al. (2017) compares daily runoff from multiple GHMs, including W3RA, and finds pronounced inter-model differences in the performance. This underlines the importance of hydrological model uncertainty. The GHM W3RA obtained moderate to good scores (Beck et al., 2017). Our results show that W3RA overestimates actual evaporation in comparison to GLEAM, which possibly results in an underestimation of discharge in both the Rhine and the Mississippi basin.

\subsection{Extrapolation of results to other basins}

This study focuses on the effect of resolution of a GCM and a GHM in modelling the hydrological cycle for the Rhine and Mississippi basins. These two well-measured basins only represent a subsample of the global diversity of catchments. Nonetheless, the conclusions from this study could be used as a guideline when assessing the benefits of resolution increases in modelling the hydrological cycle of other basins with comparable characteristics.

Our conjecture is that the improvements in the simulated hydrological cycle that is found in the Rhine basin will be valid for basins situated along mid-latitude storm-track extensions, where precipitation related to large-scale synoptic weather systems dominates total precipitation. Therefore, for those basins improvements in the hydrological cycle can be expected when higher-resolution GCMs are used. For the Mississippi basin, no clear improvements in precipitation were found with increased resolution. This is possibly due to the representation of atmospheric convection. We may expect large improvements in the coming decades, when running convection-permitting GCMs becomes feasible for climate studies (Liu et al., 2017; Prein et al., 2017). 


\section{Summary and conclusions}

We study the benefits of increased spatial resolution in global simulations of the hydrological cycle. In our set-up, we force a global hydrological model (GHM) with output from a global climate model (GCM). The GHM is run at $0.5^{\circ}$ (low) and $0.05^{\circ}$ (high) resolution, whereas the GCM is run at $1.125^{\circ}$ (low) and $0.25^{\circ}$ (high) resolution. This yields four combinations that are thoroughly compared in this paper. We do not modify the representation of physical processes in the models when increasing the spatial resolution, in order to be able to compare the effects of resolution alone. We analyse three main components of the hydrological cycle: precipitation, actual evaporation, and discharge. We focus on two river basins with contrasting climatic drivers and for which enough verification data exist: the Rhine and Mississippi basins.

By increasing the resolution of the EC-Earth GCM from $\sim 120 \mathrm{~km}^{2}\left(1.125^{\circ}\right)$ to $\sim 25 \mathrm{~km}^{2}\left(0.25^{\circ}\right)$, precipitation over the Rhine basin improves significantly, caused by the better represented large-scale circulation patterns (Van Haren et al., 2015). Therefore, we suggest using high-resolution simulations on a global scale when studying climatic impacts on the Rhine basin. The climatic drivers of the Mississippi basin are related to local convective events, large-scale weather systems from the Pacific, and moisture transport from the Caribbean, possibly associated with tropical storms. Our results show that the increased resolution GCM $\left(\sim 25 \mathrm{~km}^{2}\right)$ hardly affects precipitation over the Mississippi basin. Likely this is because the spatial scales involved in convective precipitation are still too small to be resolved, and the model therefore relies on the same parameterizations for convection at low and high resolutions. For a good representation of the hydrological cycle over the Mississippi basin, we therefore recommend using convection-permitting models to explicitly resolve moist convective processes.

The (improved) monthly-averaged precipitation from the GCM is reflected in (improved) monthly-averaged actual evaporation and discharge from the GHM. Thus, the monthly-averaged discharge of the Rhine is better simulated with high-resolution GCM input, although we did not find improvements in the representation of extreme streamflow events. For the Mississippi basin, no substantial differences in precipitation and discharge were found between the high- and low-resolution GCM and the high- and lowresolution GHM.

To increase the model resolution of the GHM, we have remapped the parameters from the 0.5 to the $0.05^{\circ}$ resolution, except for orography and vegetation, where we used high-resolution information. With these settings for the highresolution GHM $\left(\sim 5 \mathrm{~km}^{2}\right)$, no significant changes in discharge were found for both basins. Improvements in discharge are expected with high-resolution GHMs when hydrological processes and parameters are better understood and described. Based on the results of our study, we con- clude that due to the clearly distinct response of the chosen river basins to resolution increase, the route from improved resolution to better results is a challenging one. Our study, however, provides new and valuable insights on what to expect from spatial resolution increase when modelling the hydrological cycle for basins in the mid-latitude storm tracks or in convection-dominated regions.

Code and data availability. The observational data (precipitation from E-OBS and CPC, actual evaporation from GLEAM and discharge from GRDC) used in this study are stored in a repository: https://doi.org/10.4121/uuid: b7b988fc-f5c8-4ce1-8e33-47f31d04a99d (Benedict, 2018). A description of how to process the data to obtain the results of this paper is presented in the README file https://data.4tu.nl/repository/uuid: c3b6e367-8215-4640-81d2-9f74994e65f4. The parameter fields of the hydrological model and the routing module are also stored in this repository, together with the executables of these models. The main description of the global hydrological model W3RA code and parameters is given here (Van Dijk, 2010): http://www.clw.csiro.au/publications/waterforahealthycountry/ 2010/wfhc-aus-water-resources-assessment-system.pdf. The model code is also open source and online available on Github: https://github.com/openstreams/wflow/blob/master/wflow-py/ wflow/wflow_w3ra.py. The EC-Earth data and the output of the hydrological model are available upon request to the authors.

Author contributions. All authors have contributed to the design of this study. IB performed the simulations and data analyses. IB wrote the paper with major input from $\mathrm{CvH}$ and further contributions from $\mathrm{AW}$ and $\mathrm{WH}$.

Competing interests. The authors declare that they have no conflict of interest.

Acknowledgements. We would like to thank Marie-Estelle Demory, Hubert H. G. Savenije, and one anonymous reviewer for their valuable comments which considerably improved this paper. Imme Benedict acknowledges funding from the Netherlands Organization for Scientific Research (NWO), project number 869.15.004.

Edited by: Stan Schymanski

Reviewed by: Marie-Estelle Demory, Hubert H. G. Savenije, and one anonymous referee 


\section{References}

Balsamo, G., Beljaars, A., Scipal, K., Viterbo, P., van den Hurk, B., Hirschi, M., and Betts, A. K.: A revised hydrology for the ECMWF model: Verification from field site to terrestrial water storage and impact in the Integrated Forecast System, J. Hydrometeorol., 10, 623-643, 2009.

Balsamo, G., Boussetta, S., Lopez, P., and Ferranti, L.: Evaluation of ERA-Interim and ERA-Interim-GPCP-rescaled precipitation over the USA, ERA report series 5, ECMWF, Reading, 10 pp., 2010.

Balsamo, G., Albergel, C., Beljaars, A., Boussetta, S., Brun, E., Cloke, H., Dee, D., Dutra, E., Muñoz-Sabater, J., Pappenberger, F., de Rosnay, P., Stockdale, T., and Vitart, F.: ERAInterim/Land: a global land surface reanalysis data set, Hydrol. Earth Syst. Sci., 19, 389-407, https://doi.org/10.5194/hess-19389-2015, 2015.

Beck, H. E., van Dijk, A. I. J. M., de Roo, A., Miralles, D. G., McVicar, T. R., Schellekens, J., and Bruijnzeel, L. A.: Global-scale regionalization of hydrologic model parameters, Water Resour. Res., 52, 3599-3622, https://doi.org/10.1002/2015WR018247, 2016.

Beck, H. E., van Dijk, A. I. J. M., de Roo, A., Dutra, E., Fink, G., Orth, R., and Schellekens, J.: Global evaluation of runoff from 10 state-of-the-art hydrological models, Hydrol. Earth Syst. Sci., 21, 2881-2903, https://doi.org/10.5194/hess-21-2881-2017, 2017.

Benedict, I.: README file related to datasets of hydrological simulations of the Rhine and Mississippi basin, 4TU, Centre of Research Data, https://doi.org/10.4121/uuid:c3b6e367-8215-464081d2-9f74994e65f4, 2018.

Berghuijs, W. R., Woods, R. A., Hutton, C. J., and Sivapalan, M.: Dominant flood generating mechanisms across the United States, Geophys. Res. Lett., 43, 4382-4390, https://doi.org/10.1002/2016GL068070, 2016.

Betts, A. K., Köhler, M., and Zhang, Y.: Comparison of river basin hydrometeorology in ERA-Interim and ERA-40 reanalyses with observations, J. Geophys. Res.-Atmos., 114, D02101, https://doi.org/10.1029/2008JD010761, 2009.

Biemans, H., Hutjes, R., Kabat, P., Strengers, B., Gerten, D., and Rost, S.: Effects of precipitation uncertainty on discharge calculations for main river basins, J. Hydrometeorol., 10, 1011-1025, 2009.

Bierkens, M. F. P., Bell, V. A., Burek, P., Chaney, N., Condon, L. E., David, C. H., de Roo, A., Döll, P., Drost, N., Famiglietti, J. S., Flörke, M., Gochis, D. J., Houser, P., Hut, R., Keune, J., Kollet, S., Maxwell, R. M., Reager, J. T., Samaniego, L., Sudicky, E., Sutanudjaja, E. H., van de Giesen, N., Winsemius, H., and Wood, E. F.: Hyper-resolution global hydrological modelling: what is next?: "Everywhere and locally relevant", Hydrol. Process., 29, 310-320, https://doi.org/10.1002/hyp.10391, 2015.

Chang, E. K. M., Guo, Y., and Xia, X.: CMIP5 multimodel ensemble projection of storm track change under global warming: CMIP5 model-projected storm track change, J. Geophys. Res.Atmos., 117, D23118, https://doi.org/10.1029/2012JD018578, 2012.

Davini, P., Corti, S., D’Andrea, F., Rivière, G., and von Hardenberg, J.: Improved Winter European Atmospheric Blocking Frequencies in High-Resolution Global Climate Simulations, J. Adv. Model. Earth Syst., 9, 2615-2634, 2017a.
Davini, P., von Hardenburg, J., Corti, S., Christensen, H. M., Juricke, S., Subramanian, A., Watson, P. A., Weisheimer, A., and Palmer, T. N.: Climate SPHINX: evaluating the impact of resolution and stochastic physics parameterisations in the ECEarth global climate model, Geosci. Model Dev., 10, 1383-1402, https://doi.org/10.5194/gmd-10-1383-2017, 2017b.

Dee, D. P., Uppala, S. M., Simmons, A. J., Berrisford, P., Poli, P., Kobayashi, S., Andrae, U., Balmaseda, M. A., Balsamo, G., Bauer, P., Bechtold, P., Beljaars, A. C. M., van de Berg, L., Bidlot, J., Bormann, N., Delsol, C., Dragani, R., Fuentes, M., Geer, A. J., Haimberger, L., Healy, S. B., Hersbach, H., Hólm, E. V., Isaksen, L., Kållberg, P., Köhler, M., Matricardi, M., McNally, A. P., Monge-Sanz, B. M., Morcrette, J.-J., Park, B.-K., Peubey, C., de Rosnay, P., Tavolato, C., Thépaut, J.-N., and Vitart, F.: The ERA-Interim reanalysis: configuration and performance of the data assimilation system, Q. J. Roy. Meteorol. Soc., 137, 553597, https://doi.org/10.1002/qj.828, 2011.

Delworth, T. L., Rosati, A., Anderson, W., Adcroft, A. J., Balaji, V., Benson, R., Dixon, K., Griffies, S. M., Lee, H.-C., Pacanowski, R. C., Vecchi, G. A., Wittenberg, A. T., Zeng, F., and Zhang, R.: Simulated climate and climate change in the GFDL CM2.5 highresolution coupled climate model, J. Climate, 25, 2755-2781, 2012.

Demory, M.-E., Vidale, P. L., Roberts, M. J., Berrisford, P., Strachan, J., Schiemann, R., and Mizielinski, M. S.: The role of horizontal resolution in simulating drivers of the global hydrological cycle, Clim. Dynam., 42, 2201-2225, https://doi.org/10.1007/s00382-013-1924-4, 2014.

Disse, M. and Engel, H.: Flood events in the Rhine basin: genesis, influences and mitigation, Nat. Hazards, 23, 271-290, 2001.

Duffy, P., Govindasamy, B., Iorio, J., Milovich, J., Sperber, K., Taylor, K., Wehner, M., and Thompson, S.: High-resolution simulations of global climate, part 1: present climate, Clim. Dynam., 21, 371-390, 2003.

Efron, B. and Tibshirani, R. J.: An introduction to the bootstrap, CRC Press, USA, 1994.

Fekete, B. M., Vörösmarty, C. J., Roads, J. O., and Willmott, C. $\mathrm{J} .:$ Uncertainties in precipitation and their impacts on runoff estimates, J. Climate, 17, 294-304, 2004.

Fowler, H. J., Blenkinsop, S., and Tebaldi, C.: Linking climate change modelling to impacts studies: recent advances in downscaling techniques for hydrological modelling, Int. J. Climatol., 27, 1547-1578, https://doi.org/10.1002/joc.1556, 2007.

Gao, H., Hrachowitz, M., Fenicia, F., Gharari, S., and Savenije, H. H. G.: Testing the realism of a topography-driven model (FLEX-Topo) in the nested catchments of the Upper Heihe, China, Hydrol. Earth Syst. Sci., 18, 1895-1915, https://doi.org/10.5194/hess-18-1895-2014, 2014a.

Gao, H., Hrachowitz, M., Schymanski, S., Fenicia, F., Sriwongsitanon, N., and Savenije, H.: Climate controls how ecosystems size the root zone storage capacity at catchment scale, Geophys. Res. Lett., 41, 7916-7923, 2014b.

Gao, H., Hrachowitz, M., Sriwongsitanon, N., Fenicia, F., Gharari, S., and Savenije, H. H.: Accounting for the influence of vegetation and landscape improves model transferability in a tropical savannah region, Water Resour. Res., 52, 7999-8022, 2016.

GRDC: GRDC in the Bundesanstalt fuer Gewaesserkunde, Tech. rep., Koblenz, Germany, available at: http://grdc.bafg.de (last access: 12 March 2019), 2007. 
Haarsma, R. J., Hazeleger, W., Severijns, C., de Vries, H., Sterl, A., Bintanja, R., van Oldenborgh, G. J., and van den Brink, H. W.: More hurricanes to hit western Europe due to global warming, Geophys. Res. Lett., 40, 1783-1788, https://doi.org/10.1002/grl.50360, 2013.

Haarsma, R. J., Roberts, M. J., Vidale, P. L., Senior, C. A., Bellucci, A., Bao, Q., Chang, P., Corti, S., Fuckar, N. S., Guemas, V., von Hardenberg, J., Hazeleger, W., Kodama, C., Koenigk, T., Leung, L. R., Lu, J., Luo, J.-J., Mao, J., Mizielinski, M. S., Mizuta, R., Nobre, P., Satoh, M., Scoccimarro, E., Semmler, T., Small, J., and von Storch, J.-S.: High Resolution Model Intercomparison Project (HighResMIP v1.0) for CMIP6, Geosci. Model Dev., 9, 4185-4208, https://doi.org/10.5194/gmd-9-4185-2016, 2016.

Haddeland, I., Clark, D. B., Franssen, W., Ludwig, F., Voß, F., Arnell, N. W., Bertrand, N., Best, M., Folwell, S., Gerten, D., Gomes, S., Gosling, S. N., Hagemann, S., Hanasaki, N., Harding, R., Heinke, J., Kabat, P., Koirala, S., Oki, T., Polcher, J., Stacke, T., Viterbo, P., Weedon, G. P., and Yeh, P.: Multimodel Estimate of the Global Terrestrial Water Balance: Setup and First Results, J. Hydrometeorol., 12, 869-884, https://doi.org/10.1175/2011JHM1324.1, 2011.

Haylock, M. R., Hofstra, N., Klein Tank, A. M. G., Klok, E. J., Jones, P. D., and New, M.: A European daily highresolution gridded data set of surface temperature and precipitation for 1950-2006, J. Geophys. Res., 113, D20119, https://doi.org/10.1029/2008JD010201, 2008.

Hazeleger, W., Severijns, C., Semmler, T., Stefanescu, S., Yang, S., Wang, X., Wyser, K., Dutra, E., Baldasano, J. M., Bintanja, R., Bougeault, P., Caballero, R., Ekman, A. M. L., Christensen, J. H., van den Hurk, B., Jimenez, P., Jones, C., Kållberg, P., Koenigk, T., McGrath, R., Miranda, P., Van Noije, T., Palmer, T., Parodi, J. A., Schmith, T., Selten, F., Storelvmo, T., Sterl, A., Tapamo, H., Vancoppenolle, M., Viterbo, P., and Willén, U.: EC-Earth: A Seamless Earth-System Prediction Approach in Action, B. Am. Meteorol. Soc., 91, 1357-1363, https://doi.org/10.1175/2010BAMS2877.1, 2010.

Hazeleger, W., Wang, X., Severijns, C., Ştefănescu, S., Bintanja, R., Sterl, A., Wyser, K., Semmler, T., Yang, S., Van den Hurk, B., van Noije, T., van der Linden, E., and van der Wiel, K.: ECEarth V2.2: description and validation of a new seamless earth system prediction model, Clim. Dynam., 39, 2611-2629, 2012.

Hazeleger, W., van den Hurk, B., Min, E., van Oldenborgh, G., Petersen, A., Stainforth, D., Vasileiadou, E., and Smith, L.: Tales of future weather, Nat. Clim. Change, 5, 107-113, https://doi.org/10.1038/nclimate2450, 2015.

Hegnauer, M., Beersma, J. J., van den Boogaard, H. F. P., Buishand, T. A., and Passchier, R. H.: Publications, presentations and other activities Generator of Rainfall and Discharge Extremes (GRADE) for the Rhine and Meuse basins, Final report of GRADE 2.0 2014, 1209424-004, Deltares, Delft, 2014.

Henn, B., Newman, A. J., Livneh, B., Daly, C., and Lundquist, J. D.: An assessment of differences in gridded precipitation datasets in complex terrain, J. Hydrol., 556, 1205-1219, https://doi.org/10.1016/j.jhydrol.2017.03.008, 2017.

Higgins, R. W., Shi, W., Yarosh, E., and Joyce, R.: Improved United States Precipitation Quality Control System and Analysis, ATLAS No. 7, NCEP/Climate Prediction Center, Camp Springs, USA, 40 pp., 2000.
Hodges, K. I., Lee, R. W., and Bengtsson, L.: A comparison of extratropical cyclones in recent reanalyses ERA-Interim, NASA MERRA, NCEP CFSR, and JRA-25, J. Climate, 24, 4888-4906, 2011.

Hofstra, N., Haylock, M., New, M., and Jones, P. D.: Testing EOBS European high-resolution gridded data set of daily precipitation and surface temperature, J. Geophys. Res., 114, D21101, https://doi.org/10.1029/2009JD011799, 2009.

Hohenegger, C., Brockhaus, P., Bretherton, C. S., and Schär, C.: The soil moisture-precipitation feedback in simulations with explicit and parameterized convection, J. Climate, 22, 5003-5020, 2009.

Hrachowitz, M., Savenije, H., Blöschl, G., McDonnell, J., Sivapalan, M., Pomeroy, J., Arheimer, B., Blume, T., Clark, M., Ehret, U., Fenicia, F., Freer, J. E., Gelfan, A., Gupta, H. V., Hughes, D. A., Hut, R. W., Montanari, A., Pande, S., Tetzlaff, D., Troch, P. A., Uhlenbrook, S., Wagener, T., Winsemius, H. C., Woods, R. A., Zehe, E., and Cudennec, C.: A decade of Predictions in Ungauged Basins (PUB) - a review, Hydrolog. Sci. J., 58, 1198-1255, 2013.

Iorio, J. P., Duffy, P., Govindasamy, B., Thompson, S. L., Khairoutdinov, M., and Randall, D.: Effects of model resolution and subgrid-scale physics on the simulation of precipitation in the continental United States, Clim. Dynam., 23, 243-258, https://doi.org/10.1007/s00382-004-0440-y, 2004.

Jacob, D., Petersen, J., Eggert, B., Alias, A., Christensen, O. B., Bouwer, L. M., Braun, A., Colette, A., Déqué, M., Georgievski, G., Georgopoulou, E., Gobiet, A., Menut, L., Nikulin, G., Haensler, A., Hempelmann, N., Jones, C., Keuler, K., Kovats, S., Kröner, N., Kotlarski, S., Kriegsmann, A., Martin, E., van Meijgaard, E., Moseley, C., Pfeifer, S., Preuschmann, S., Radermacher, C., Radtke, K., Rechid, D., Rounsevell, M., Samuelsson, P., Somot, S., Soussana, J.-F., Teichmann, C., Valentini, R., Vautard, R., Weber, B., and Yiou, P.: EURO-CORDEX: new highresolution climate change projections for European impact research, Reg. Environ. Change, 14, 563-578, 2014.

Jung, T., Miller, M., Palmer, T., Towers, P., Wedi, N., Achuthavarier, D., Adams, J., Altshuler, E., Cash, B., Kinter III, J., Marx, L., Stan, C., and Hodges, K. I.: High-resolution global climate simulations with the ECMWF model in Project Athena: Experimental design, model climate, and seasonal forecast skill, J. Climate, 25, 3155-3172, 2012.

Kew, S. F., Selten, F. M., Lenderink, G., and Hazeleger, W.: Robust assessment of future changes in extreme precipitation over the Rhine basin using a GCM, Hydrol. Earth Syst. Sci., 15, 11571166, https://doi.org/10.5194/hess-15-1157-2011, 2011.

Liu, C., Ikeda, K., Rasmussen, R., Barlage, M., Newman, A. J., Prein, A. F., Chen, F., Chen, L., Clark, M., Dai, A., Dudhia, J., Eidhammer, T., Gochis, D., Gutmann, E., Kurkute, S., Li, Y., Thompson, G., and Yates, D.: Continental-scale convectionpermitting modeling of the current and future climate of North America, Clim. Dynam., 49, 71-95, 2017.

Lundquist, J. D., Hughes, M., Henn, B., Gutmann, E. D., Livneh, B., Dozier, J., and Neiman, P.: High-Elevation Precipitation Patterns: Using Snow Measurements to Assess Daily Gridded Datasets across the Sierra Nevada, California, J. Hydrometeorol., 16, 1773-1792, https://doi.org/10.1175/JHM-D-15-0019.1, 2015.

Manganello, J. V., Hodges, K. I., Kinter III, J. L., Cash, B. A., Marx, L., Jung, T., Achuthavarier, D., Adams, J. M., Altshuler, E., Huang, B., Jin, E. K., Stan, C., Towers, P., and Wedi, N.: Tropi- 
cal cyclone climatology in a 10-km global atmospheric GCM: toward weather-resolving climate modeling, J. Climate, 25, 38673893, 2012.

Maraun, D., Shepherd, T. G., Widmann, M., Zappa, G., Walton, D., Gutiérrez, J. M., Hagemann, S., Richter, I., Soares, P. M., Hall, A., and Mearns, L. O.: Towards process-informed bias correction of climate change simulations, Nat. Clim. Change, 7, 764-773, 2017.

Martens, B., Miralles, D. G., Lievens, H., van der Schalie, R., de Jeu, R. A. M., Fernández-Prieto, D., Beck, H. E., Dorigo, W. A., and Verhoest, N. E. C.: GLEAM v3: satellite-based land evaporation and root-zone soil moisture, Geosci. Model Dev., 10, 1903-1925, https://doi.org/10.5194/gmd-10-1903-2017, 2017.

McCabe, G. J., Hay, L. E., and Clark, M. P.: Rain-on-snow events in the western United States, B. Am. Meteorol. Soc., 88, 319-328, 2007.

Meehl, G. A., Moss, R., Taylor, K. E., Eyring, V., Stouffer, R. J., Bony, S., and Stevens, B.: Climate model intercomparisons: preparing for the next phase, Eos Trans. Am. Geophys. Un., 95, 77-78, 2014.

Melsen, L., Teuling, A., Torfs, P., Zappa, M., Mizukami, N., Clark, M., and Uijlenhoet, R.: Representation of spatial and temporal variability in large-domain hydrological models: case study for a mesoscale pre-Alpine basin, Hydrol. Earth Syst. Sci., 20, $2207-$ 2226, https://doi.org/10.5194/hess-20-2207-2016, 2016.

Moezzi, M., Janda, K. B., and Rotmann, S.: Using stories, narratives, and storytelling in energy and climate change research, Energy Res. Social Sci., 31, 1-10, 2017.

Monteith, J. L.: Evaporation and environment, in the state and movement of water in living organisms, in: Symp. Soc. Exp. Biol., Academic Press, 205-234, 1965.

Photiadou, C. S., Weerts, A. H., and van den Hurk, B. J. J. M.: Evaluation of two precipitation data sets for the Rhine River using streamflow simulations, Hydrol. Earth Syst. Sci., 15, 3355-3366, https://doi.org/10.5194/hess-15-3355-2011, 2011.

Poli, P., Hersbach, H., Dee, D. P., Berrisford, P., Simmons, A. J., Vitart, F., Laloyaux, P., Tan, D. G., Peubey, C., Thépaut, J.-N., Trémolet, Y., Hólm, E. V., Bonavita, M., Isaksen, L., and Fisher, M.: ERA-20C: An atmospheric reanalysis of the twentieth century, J. Climate, 29, 4083-4097, 2016.

Prein, A. F. and Gobiet, A.: Impacts of uncertainties in European gridded precipitation observations on regional climate analysis, Int. J. Climatol., 37, 305-327, 2017.

Prein, A. F., Liu, C., Ikeda, K., Bullock, R., Rasmussen, R. M., Holland, G. J., and Clark, M.: Simulating North American mesoscale convective systems with a convection-permitting climate model, Clim. Dynam., 1-16, https://doi.org/10.1007/s00382-017-39932, 2017.

Priestley, C. and Taylor, R.: On the assessment of surface heat flux and evaporation using large-scale parameters, Mon. Weather Rev., 100, 81-92, 1972.

Samaniego, L., Kumar, R., and Attinger, S.: Multiscale parameter regionalization of a grid-based hydrologic model at the mesoscale, Water Resour. Res., 46, W05523, https://doi.org/10.1029/2008WR007327, 2010.

Scaife, A. A., Copsey, D., Gordon, C., Harris, C., Hinton, T., Keeley, S., O’Neill, A., Roberts, M., and Williams, K.: Improved Atlantic winter blocking in a climate model, Geophys. Res. Lett., 38, L23703, https://doi.org/10.1029/2011GL049573, 2011.
Schellekens, J.: OpenStreams Wflow Documentation, available at: http://wflow.readthedocs.io (last access: 12 March 2019), 2016.

Schellekens, J., Dutra, E., Martínez-de la Torre, A., Balsamo, G., van Dijk, A., Sperna Weiland, F., Minvielle, M., Calvet, J.-C., Decharme, B., Eisner, S., Fink, G., Flörke, M., Peßenteiner, S., van Beek, R., Polcher, J., Beck, H., Orth, R., Calton, B., Burke, S., Dorigo, W., and Weedon, G. P.: A global water resources ensemble of hydrological models: the eartH2Observe Tier-1 dataset, Earth Syst. Sci. Data, 9, 389-413, https://doi.org/10.5194/essd-9-389-2017, 2017.

Schiemann, R., Vidale, P. L., Shaffrey, L. C., Johnson, S. J., Roberts, M. J., Demory, M.-E., Mizielinski, M. S., and Strachan, J.: Mean and extreme precipitation over European river basins better simulated in a $25 \mathrm{~km}$ AGCM, Hydrol. Earth Syst. Sci., 22, 3933-3950, https://doi.org/10.5194/hess-22-3933-2018, 2018.

Shabalova, M. V., v. Deursen, W. P. A., and Buishand, T. A.: Assessing future discharge of the river Rhine using regional climate model integrations and a hydrological model, Clim. Res., 23, 233-246, https://doi.org/10.3354/cr023233, 2003.

Stott, P. A., Allen, M., Christidis, N., Dole, R. M., Hoerling, M., Huntingford, C., Pall, P., Perlwitz, J., and Stone, D.: Attribution of weather and climate-related events, in: Climate Science for Serving Society, Springer, Dordrecht, 307-337, 2013.

Strachan, J., Vidale, P. L., Hodges, K., Roberts, M., and Demory, M.-E.: Investigating global tropical cyclone activity with a hierarchy of AGCMs: The role of model resolution, J. Climate, 26, 133-152, 2013.

Sutanudjaja, E. H., van Beek, R., Wanders, N., Wada, Y., Bosmans, J. H. C., Drost, N., van der Ent, R. J., de Graaf, I. E. M., Hoch, J. M., de Jong, K., Karssenberg, D., López López, P., Peßenteiner, S., Schmitz, O., Straatsma, M. W., Vannametee, E., Wisser, D., and Bierkens, M. F. P.: PCR-GLOBWB 2: a 5?arcmin global hydrological and water resources model, Geosci. Model Dev., 11, 2429-2453, https://doi.org/10.5194/gmd-11-2429-2018, 2018.

Szczypta, C., Decharme, B., Carrer, D., Calvet, J.-C., Lafont, S., Somot, S., Faroux, S., and Martin, E.: Impact of precipitation and land biophysical variables on the simulated discharge of European and Mediterranean rivers, Hydrol. Earth Syst. Sci., 16, 3351-3370, https://doi.org/10.5194/hess-16-3351-2012, 2012.

Taylor, C. M., de Jeu, R. A., Guichard, F., Harris, P. P., and Dorigo, W. A.: Afternoon rain more likely over drier soils, Nature, 489, 423-426, 2012.

Taylor, K. E., Stouffer, R. J., and Meehl, G. A.: An overview of CMIP5 and the experiment design, B. Am. Meteorol. Soc., 93, 485-498, 2012.

Turco, M., Zollo, A. L., Ronchi, C., De Luigi, C., and Mercogliano, P.: Assessing gridded observations for daily precipitation extremes in the Alps with a focus on northwest Italy, Nat. Hazards Earth Syst. Sci., 13, 1457-1468, https://doi.org/10.5194/nhess13-1457-2013, 2013.

Ulbrich, U. and Fink, A.: The January 1995 flood in Germany: meteorological versus hydrological causes, Phys. Chem. Earth, 20, 439-444, 1995.

Van den Hurk, B. J., Viterbo, P., Beljaars, A., and Betts, A.: O ine validation of the ERA40 surface scheme, ECMWF Tech. Mem. 295, ECMWF, Reading, 1-42, 2000.

van den Hurk, B. J., Viterbo, P., and Los, S. O.: Impact of leaf area index seasonality on the annual land surface evaporation in a 
global circulation model, J. Geophys. Res.-Atmos., 108, 4191, https://doi.org/10.1029/2002JD002846, 2003.

van der Wiel, K., Kapnick, S. B., Vecchi, G. A., Cooke, W. F., Delworth, T. L., Jia, L., Murakami, H., Underwood, S., and Zeng, F.: The Resolution Dependence of Contiguous U.S. Precipitation Extremes in Response to $\mathrm{CO}_{2}$ Forcing, J. Climate, 29, 79918012, https://doi.org/10.1175/JCLI-D-16-0307.1, 2016.

Van der Wiel, K., Kapnick, S. B., Vecchi, G. A., Smith, J. A., Milly, P. C., and Jia, L.: 100-Year Lower Mississippi Floods in a Global Climate Model: Characteristics and Future Changes, J. Hydrometeorol., 19, 1547-1563, 2018.

Van Dijk, A. I. J. M.: AWRA Technical Report 3, Landscape Model (version 0.5) Technical Description, WIRADA/CSIRO Water for a Healthy Country Flagship, Canberra, 2010a.

van Dijk, A. I. J. M.: Climate and terrain factors explaining streamflow response and recession in Australian catchments, Hydrol. Earth Syst. Sci., 14, 159-169, https://doi.org/10.5194/hess-14159-2010, 2010b.

van Dijk, A. I. J. M. and Renzullo, L. J.: Water resource monitoring systems and the role of satellite observations, Hydrol. Earth Syst. Sci., 15, 39-55, https://doi.org/10.5194/hess-15-39-2011, 2011.

Van Dijk, A. I. J. M. and Warren, G.: The Australian Water Resources Assessment System, Technical Report 4, Landscape Model (version 0.5) Evaluation Against Observations, CSIRO: Water for a Healthy Country National Research Flagship, Sydney, 2010.

van Dijk, A. I. J. M., Peña-Arancibia, J. L., Wood, E. F., Sheffield, J., and Beck, H. E.: Global analysis of seasonal streamflow predictability using an ensemble prediction system and observations from 6192 small catchments worldwide: Global Analysis of Seasonal Streamflow Predictability, Water Resour. Res., 49, 27292746, https://doi.org/10.1002/wrcr.20251, 2013.

van Haren, R., van Oldenborgh, G. J., Lenderink, G., and Hazeleger, W.: Evaluation of modeled changes in extreme precipitation in Europe and the Rhine basin, Environ. Res. Lett., 8, 014053, https://doi.org/10.1088/1748-9326/8/1/014053, 2013.

Van Haren, R., Haarsma, R. J., Van Oldenborgh, G. J., and Hazeleger, W.: Resolution Dependence of European Precipitation in a State-of-the-Art Atmospheric General Circulation Model, J. Climate, 28, 5134-5149, https://doi.org/10.1175/JCLID-14-00279.1, 2015. van Osnabrugge, B., Weerts, A., and Uijlenhoet, R.: genRE: A Method to Extend Gridded Precipitation Climatology Data Sets in Near Real-Time for Hydrological Forecasting Purposes, Water Resour. Res., 53, 9284-9303, 2017.

Viterbo, P. and Beljaars, A. C. M.: An Improved Land Surface Parameterization Scheme in the ECMWF Model and Its Validation, J. Climate, 8, 2716-2748, 1995.

Wang-Erlandsson, L., Bastiaanssen, W. G. M., Gao, H., Jägermeyr, J., Senay, G. B., van Dijk, A. I. J. M., Guerschman, J. P., Keys, P. W., Gordon, L. J., and Savenije, H. H. G.: Global root zone storage capacity from satellite-based evaporation, Hydrol. Earth Syst. Sci., 20, 1459-1481, https://doi.org/10.5194/hess-20-14592016, 2016.

Wehner, M. F., Smith, R. L., Bala, G., and Duffy, P.: The effect of horizontal resolution on simulation of very extreme US precipitation events in a global atmosphere model, Clim. Dynam., 34, 241-247, https://doi.org/10.1007/s00382-009-0656-y, 2010.

Wood, A. W., Leung, L. R., Sridhar, V., and Lettenmaier, D.: Hydrologic implications of dynamical and statistical approaches to downscaling climate model outputs, Climatic change, 62, 189216, 2004.

Wood, E. F., Roundy, J. K., Troy, T. J., van Beek, L. P. H., Bierkens, M. F. P., Blyth, E., de Roo, A., Döll, P., Ek, M., Famiglietti, J., Gochis, D., van de Giesen, N., Houser, P., Jaffé, P. R., Kollet, S., Lehner, B., Lettenmaier, D. P., Peters-Lidard, C., Sivapalan, M., Sheffield, J., Wade, A., and Whitehead, P.: Hyperresolution global land surface modeling: Meeting a grand challenge for monitoring Earth's terrestrial water, Water Resour. Res., 47, W05301, https://doi.org/10.1029/2010WR010090, 2011.

Zappa, G. and Shepherd, T. G.: Storylines of atmospheric circulation change for European regional climate impact assessment, J. Climate, 30, 6561-6577, 2017.

Zappa, G., Shaffrey, L. C., Hodges, K. I., Sansom, P. G., and Stephenson, D. B.: A multimodel assessment of future projections of North Atlantic and European extratropical cyclones in the CMIP5 climate models, J. Climate, 26, 5846-5862, 2013. 